\title{
Article \\ Oil Market Factors as a Source of Commonality in Liquidity in International Equity Markets
}

\author{
Abdulrahman Alhassan ${ }^{1, *}$, Atsuyuki Naka ${ }^{2}$ and Abdullah Noman ${ }^{3}$ \\ 1 Department of Finance, King Saud University, Riyadh 11451, Saudi Arabia \\ 2 Department of Economics and Finance, University of New Orleans, New Orleans, LA 70148, USA; \\ anaka@uno.edu \\ 3 Department of Accounting and Finance, University of North Carolina, Pembroke, NC 28372, USA; \\ abdullah.noman@uncp.edu \\ * Correspondence: alabdulrahman@ksu.edu.sa
}

check for

updates

Citation: Alhassan, Abdulrahman,

Atsuyuki Naka, and Abdullah

Noman. 2021. Oil Market Factors as a

Source of Commonality in Liquidity

in International Equity Markets.

Journal of Risk and Financial

Management 14: 372. https://

doi.org/10.3390/jrfm14080372

Academic Editor:

Charlotte Christiansen

Received: 30 June 2021

Accepted: 5 August 2021

Published: 13 August 2021

Publisher's Note: MDPI stays neutral with regard to jurisdictional claims in published maps and institutional affiliations.

Copyright: (c) 2021 by the authors. Licensee MDPI, Basel, Switzerland. This article is an open access article distributed under the terms and conditions of the Creative Commons Attribution (CC BY) license (https:// creativecommons.org/licenses/by/ $4.0 /)$.

\begin{abstract}
When stock markets are less liquid or illiquid, investors are expected to require compensation for taking the risk of not being able to sell quickly. Many studies have documented the existence of the co-movements (commonality) of market liquidity in equity markets as a priced factor. The primary objective of this paper is to introduce the oil market as a potential source of commonality in liquidity. We hypothesize that conditions specific to the oil market can contribute to commonality in liquidity affecting both supply-side and demand-side factors because of its importance to the global economy in general. To this aim, a sample of firms is drawn from 50 countries spanning the period from January 1995 to December 2015. We examine two channels that transmit the effect of oil market movements to the liquidity commonality in international equity markets, namely, oil price returns and oil price volatility. Seemingly unrelated regressions (SUR) are utilized to estimate the effect of oil factors on commonality in liquidity. We find that the returns and volatility of oil prices explain the commonality in liquidity in countries with higher integration with oil markets. In addition, we show that the effect of oil volatility is more pronounced for net oil exporters as opposed to net oil importers after controlling for oil sensitivity. These results are robust to controlling for possible sources of commonality in liquidity as found in the literature and alternative estimation specifications.
\end{abstract}

Keywords: commonality in liquidity; oil market; international equity markets; oil volatility; volatility spillover; OPEC; oil exporting countries

JEL Classification: G12; G15; E44; Q02

\section{Introduction}

Stock market liquidity is defined as the ease of buying and selling a certain stock without a loss in value and is one of the most significant measures that gauge the efficiency of equity markets. If stock markets are less liquid or illiquid, investors are expected to require compensation for taking the risk of not being able to sell quickly when trading stocks. Many studies have documented the existence of the co-movements (commonality) of market liquidity in equity markets and that it is a priced factor. ${ }^{1}$ Acharya and Pedersen (2005) proposed liquidity as a systematic effect in an asset-pricing model. Karolyi et al. (2012) examined commonality in liquidity among stocks within countries and documented its existence using 48 national stock markets. Marshall et al. (2013) found strong commonality in liquidity in 16 different commodity futures markets and noted that they are affected by the liquidity of stock markets. Koch et al. (2016) also showed that stocks with high mutual fund ownership have more commonality in liquidity than those with low mutual fund ownership. Similarly, Deng et al. (2018) found a positive relationship between foreign ownership and commonality in liquidity. In a large sample of 39 markets, Moshirian et al. (2017) 
found that commonality in liquidity is a priced factor, and these pricing effects are stronger in developed markets than in emerging markets.

Factors affecting commonality in liquidity are generally divided into two sides, namely, supply-side and demand-side factors. Supply-side factors are related to the sources of funds for the investors. For example, Coughenour and Saad (2004) showed that the co-movements of liquidity in certain stocks are caused by specialist firms that provide liquidity for these stocks within their portfolios. Hameed et al. (2010) found that commonality in liquidity drops with large negative market returns because the aggregate collaterals of lending agents decline, followed by agents being forced to liquidate their collaterals, which is less likely to provide liquidity to the market. Conversely, demand-side factors include correlations in trading activity, structure of ownership, and exchange rates. Kamara et al. (2008) found a positive association between increases in institutional trading and commonality in liquidity, confirming the study of Gorton and Pennacchi (1993), who predicted that equity basket trading would increase commonality in liquidity for the stocks in the basket. Chordia et al. (2000) and Hasbrouck and Seppi (2001) found evidence that correlations in trading activities were a source of co-movements in individual stocks' liquidity. Karolyi et al. (2012) showed that demand-side factors, including institutional and foreign investors and correlated trading activities, explained the level of commonality in liquidity in most of the countries in their sample. Dang et al. (2015a) found that the commonality in liquidity of cross-listed firms is lower for home markets and higher for host markets after cross-listing.

A number of recent studies have investigated other aspects of the commonality in liquidity in cross-sections of assets. For example, Isshaq and Faff (2016) explored the relationship between firm-level fundamentals and commonality in liquidity and reported that firms with a low (high) level of profitability volatility will have higher (lower) commonality in liquidity. The negative relationship between commonality in liquidity and volatility in firm-level profitability arises when a firm is considered as a "reference stock" by the investors. This finding is consistent with demand-side sources of commonality in liquidity. Another study by Hoesli et al. (2017) concluded that demand-side factors of commonality in liquidity are more prevalent than supply-side factors. The authors examined commonality in REIT stocks and found that commonality is higher in bad market conditions than in good market conditions. Moriyasu et al. (2018) examined the impact of algorithm trading on liquidity and found that they are positively related. Furthermore, they showed that large market declines can have a weakening positive impact on the relationship between algorithm trading and liquidity. ${ }^{2}$ Yoon et al. (2019) applied the network spillover methodology to understand the nature of spillover shock transmission across a variety of markets, including equity, debt, currency, and commodity markets. Their study provides evidence of both the static and dynamic nature of information spillover, which have important implications for portfolio management and strategies. Overall, these studies indicate that market- and firm-level characteristics can contribute toward commonality in liquidity.

The primary objective of this paper is to introduce the oil market as a potential source of commonality in liquidity. Within this broad objective, we explore the role of the oil market in the context of commonality in international equity markets that include both developed and emerging countries. Second, we examine the variation in the relationship between the oil market and commonality in liquidity based on the oil dependency of a country. More specifically, we hypothesize that conditions specific to the oil market can contribute to commonality in liquidity, affecting both supply-side and demand-side factors because of its importance to the global economy in general. First, we construct an oil sensitivity measure to gauge how a country's oil dependency affects commonality in liquidity in its equity market and rank countries by the degree of this oil sensitivity measure. More specifically, we define the oil sensitivity of a country as the absolute value of the difference between oil exports and imports scaled by its GDP. Second, we examine the nature of two channels that transmit the effect of oil market movements to the commonality 
in liquidity in international equity markets. These channels are oil price returns (\% changes in oil price) and oil price volatility.

This paper is the first to link the condition of the oil market to the commonality in liquidity in the global equity markets. We use a large sample of data comprising 50 countries and investigate a set of hypotheses that address the importance of the oil market in explaining commonality in liquidity in international equity markets. Existing studies suggest that commonality in liquidity is driven by a set of supply-side factors, such as the inability of lending agents to fund investors in equity markets, and by a set of demand-side factors such as correlated trading activities in equity markets. We explore the idea that conditions in the oil market, being a major global macroeconomic force, may impact both the supply- and demand- side factors that are responsible for commonality in liquidity in the equity markets.

The association between oil market conditions and macroeconomic phenomena such as economic stability, economic growth, and financial markets has been extensively studied (Hamilton 1983, 2003; Chen et al. 1986; Huang et al. 1996; and others). For example, Huang et al. (1996) illustrated the relationship between changes in oil price and stock returns and showed how the components of stock returns are functions of oil prices. Because oil is a major input in the production process in many companies, changes in oil prices and price volatility should have an impact on their future cash flows. Oil market conditions can also affect the cost of capital through its influence on interest and inflation rates in an economy. Recently, Dahl et al. (2020) examined the relationship between the crude oil and major agricultural commodities. They reported asymmetric and bidirectional flow of information spillover between the crude oil and those agricultural commodities. Many empirical studies using samples from United States companies provide supportive evidence of oil risk as a systematic pricing factor in stock markets. ${ }^{3}$ We extend this branch of the literature by addressing the question of whether oil prices and volatility affect stock prices through their impact on the commonality in liquidity. Since higher commonality in liquidity implies a higher level of liquidity risk as a systematic pricing factor, our findings on the association between oil prices and commonality in liquidity in international equity markets will have critical implications for the asset pricing literature. This line of inquiry is formalized in a set of hypotheses that aim to explore the relationship between oil market movements and liquidity commonalty in the equity market.

When an economy experiences a high level of uncertainty following fluctuations in the oil market, lending agents encounter more restrictions on their capital, which, in turn, force them to liquidate assets and reduce their ability to provide for liquidity through lending (Karolyi et al. 2012). On the demand side, if an economy is exposed to global macroeconomic factors and is also relatively highly integrated with the oil market and sensitive to its price movements, the flow of funds in that equity market will be commonly affected by investors' fear of uncertainty when oil market volatility increases. This decrease in investment flows, caused by uncertainty, will spread across individual stocks in that economy. However, during stable oil market conditions, the common fear of uncertainty plays a less important role, which results in more variation in liquidity levels across individual stocks in the economy, reducing the commonality in liquidity in equity markets. Based on the theoretical understanding outlined above, this study attempts to investigate the extent to which the oil market may explain the average commonality in liquidity of individual stocks within local equity markets.

The nature and extent of commonality in liquidity can vary substantially across economies. Several studies have found variations in commonality across different markets. For example, Brockman et al. (2009) found that Asian stock markets experienced the strongest commonality in liquidity, whereas Latin American markets have the lowest commonality in liquidity, and that local sources of commonality play a more important role than global sources in explaining firm-level commonality in liquidity. Furthermore, they examined the effect of macroeconomic announcements on commonality in liquidity across countries and found that local and US macroeconomic announcements partially explained 
commonality in liquidity across countries. Śmiech et al. (2021) investigated the impact of oil price shocks on industrial activities in four oil exporting countries, namely, Canada, Mexico, Norway, and Russia. They found that oil price related uncertainties have almost instant and profound adverse effects on the industrial production fluctuations in those countries. Karolyi et al. (2012) introduced several variables for detecting the sources of such commonality in cross-sectional and time-series analyses using a sample of 40 countries. Although economies are categorized as having different levels of financial constraint, Karolyi et al. (2012) found that the liquidity of equity markets in almost all economies tended to suffer as a result of limited funding. Most of the factors examined in the literature are common causes across many international markets. ${ }^{4}$

Using a sample of 36,930 firms from 50 countries, we show that oil returns and volatility, as transmitting channels of oil effects on commonality in liquidity, significantly explain variations in commonality in liquidity for countries with high oil sensitivity. We also find that oil volatility's effects on commonality in liquidity are both statistically and economically more significant than oil returns' effects when the equal coefficient restriction is imposed on all equations in the highly oil-sensitive group. The results also indicate that oil volatility's effects are stronger in net oil exporters as opposed to net oil importers, after controlling for oil sensitivity. We then relax the equal constraint restriction and allow the coefficients to vary across four groups, which are less oil-sensitive, highly oil-sensitive OPEC net exporters, highly oil-sensitive non-OPEC net exporters, and highly oil-sensitive net importers. Our findings suggest that oil returns have a strong impact on commonality in liquidity for OPEC members, whereas oil volatility influences commonality in liquidity in both net oil exporters and net oil importers. The results suggest that the effect of oil volatility is stronger on net oil exporters as opposed to net oil importers. Since market factors and oil factors may possibly be highly correlated, which may impact our conclusions, we repeat our estimation using oil factors that are orthogonal to market factors and find that the results do not change qualitatively. Further, our results are robust to controlling for other possible sources of commonality in liquidity as documented in the previous literature.

\section{Hypotheses and Construction of Variables}

This section describes the main hypotheses and the oil market factors, as well as the construction of variables such as the oil sensitivity measures, oil factors that consist of oil returns and volatility, and commonality in liquidity measures. We also present other variables that are considered in order to control for demand and supply sources of commonality in liquidity.

\subsection{Hypotheses}

We discuss the following hypotheses to achieve the main objectives of the paper, which are based on relevant literature focusing on the relationship between the oil market and macroeconomies in general and financial markets in particular. We hypothesize that the oil market affects the commonality in liquidity. More specifically, we propose two possible channels thorough which the oil market influences commonality in liquidity, namely, oil market returns and oil market volatility.

Hypothesis 1. Oil market returns will have significant impact on stock market commonality in liquidity. The direction of the impact will depend on whether the economy is a net oil exporter or a net oil importer. More specifically, increases in oil market returns will reduce commonality in liquidity for net oil exporters and increase it for net oil importers.

The impact of the oil market on a macroeconomy is well-documented in the literature. For example, Chiang et al. (2015) reported a significant relationship between oil market volatility and macroeconomic variables in general and stock market pricing factors in particular. The relationship between the oil market and stock market returns has also been studied extensively. Driesprong et al. (2008) found an inverse relationship between spot 
oil price returns and stock returns. Similarly, Narayan and Sharma (2011) reported that for certain US sectors, oil price movements have a significant impact on stock returns. Chiang and Hughen (2017) used oil futures prices instead of oil spot prices and found a significantly negative impact on US stock returns. Recently, Basher et al. (2018) have shown the significant impact of oil market shocks on oil-exporting countries.

Hypothesis 2. Oil market volatility will have an impact on stock market commonality in liquidity. Regarding the nature of this impact, we expect higher volatility will cause a higher level of commonality in liquidity. Therefore, the expected sign is positive on the coefficient of oil market volatility.

The relationship between oil volatility and stock market returns has been studied in depth by Christoffersen and Pan (2018). Using option-implied expected volatility, the authors found that in a cross-section of equities, returns on stocks with high exposure to the oil market are lower than those with low exposure. Such a finding is strengthened by additional findings that high oil volatility predicts lower stock market returns and higher stock market volatility. In addition, Christoffersen and Pan (2018) demonstrated that oil market volatility is related to funding constraints for financial intermediaries, including stock market brokers and dealers. This was especially true after the financialization of commodity markets. This finding is related to those of Chiang et al. (2015), who reported that oil volatility is related to the pricing of both oil- and non-oil securities via macroeconomic variables such as GDP, industrial production, and unemployment.

We expect that the relationship between commonality in liquidity and oil market factors will vary across countries because not all countries in our sample are equal in terms of their dependence on and integration with the oil market. In this paper, we introduce an oil sensitivity measure, defined as the absolute value of the difference between exports and imports of crude oil divided by GDP in billion USD dollars (constant in 2005 US dollars). This measure (Sens) is constructed as:

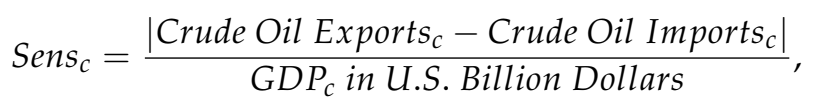

where the subscript $c$ denotes the country. The amount of exports and imports of crude oil is in thousand barrels per day. The above measure has intuitive appeal, as it provides a degree of oil dependency that separates the net exporting and net importing countries. In the case that a country exports exactly as much oil as it imports, their net zero position should make them the least sensitive to oil volatility and perfectly hedged against oil risk. It does not imply that this case is completely insensitive to oil markets; however, it is relatively less directly sensitive to oil market. This measure will provide a degree of oil dependency relative to the size of an economy. At this point, we specify another hypothesis that addresses the relationship between commonality in liquidity and oil market factors based on their oil sensitivity as described above:

Hypothesis 3. The influence of oil market factors on commonality depends on a country's level of sensitivity to the oil market. The impact will be stronger in highly oil-sensitive countries than in less oil-sensitive countries.

Finally, we conjecture that oil returns inversely affect commonality in liquidity in countries whose net position in the oil market is that of a seller (i.e., net exporters) but will positively affect commonality in liquidity in countries whose net position in the oil market is that of a buyer (i.e., net importers), although we expect oil volatility to have a positive effect on commonality in liquidity, regardless of the net position of that country. On the basis of this conjecture, we test the following hypothesis:

Hypothesis 4. The impact of oil market factors will be stronger in net exporters than in net importers. 
According to this last hypothesis, for net exporters of oil, higher oil market returns will have a positive impact on the stock market and therefore will negatively affect commonality in liquidity and a negative sign on the coefficient is expected. Conversely, for net importers, a rise in oil market returns will have a negative impact on the stock market, leading to an expected positive sign on the coefficient.

\subsection{Oil Factors}

To investigate how the oil market affects commonality in liquidity in the global equity markets, we identified two channels, namely oil price returns and volatility, which transmits oil market conditions to commonality in liquidity. The oil return is based on the log of differences in one-month crude oil futures prices traded on the New York Mercantile Exchange (NYMEX), and the volatility of oil returns is assumed to follow the GARCH process. Sadorsky (2001) showed that spot prices are more strongly affected by temporary random noise than to futures prices; Chiang and Hughen (2017) also supported the use of futures prices. ${ }^{5}$ On the basis of the Akaike information criterion and the Bayesian information criterion, we selected the time series to have the autoregressive $\operatorname{AR}(1)-G A R C H(1,1)$ process, which is expressed below:

$$
\begin{gathered}
\text { ROIL }_{t}=\alpha+\beta \text { ROIL } L_{t-1}+\varepsilon_{t} \quad \varepsilon_{t} \mid I_{t-1} \sim N\left(0, h_{t}\right) \\
\text { VOIL } L_{t}=h_{t}=\beta_{0}+\beta_{1} \varepsilon_{t-1}^{2}+\beta_{2} h_{t-1},
\end{gathered}
$$

where ROIL $L_{t}$ denotes oil returns defined as the log of difference in prices and $\varepsilon_{t}$ is the error term with a mean of zero and a conditional variance of $h_{t}$. VOIL $L_{t}$ is the proxy for oil volatility and shocks. Elyasiani et al. (2011) studied the impact of oil price returns and volatility on excess stock returns across industries in the US stock market and used the GARCH process as a proxy for oil volatility.

\subsection{The Commonality in Liquidity}

Different and competing ways can be used to construct the commonality in liquidity measure in equity markets. One method is to define commonality in liquidity as the cross-sectional average coefficients based on time-series regressions (Chordia et al. 2000; Coughenour and Saad 2004; Brockman et al. 2009; Hameed et al. 2010; Rösch and Kaserer 2013; Koch et al. 2016). Another method is to define the commonality in liquidity by using principal component analysis (Korajczyk and Sadka 2008; Marshall et al. 2013). Another approach is to compute innovations (regression errors) from individual stock liquidity by using filtering regressions and then constructing commonality in liquidity based on the goodness of fit of a regression of individual stocks. This method has been utilized by Roll (1988), Morck et al. (2000), Hameed et al. (2010), Karolyi et al. (2012), Dang et al. (2015a, 2015b), and others. We use a two-step approach to construct our commonality in liquidity measure, which is the goodness of fit $\left(R^{2}\right)$ from regressions of the changes in liquidity of individual stocks. ${ }^{6}$ We summarize each step of estimating the commonality in liquidity measure below.

Our liquidity measure ( $(i q)$ is based on Amihud's (2002) illiquidity, which only requires daily data. Following Karolyi et al. (2012), we add a constant and take the log to avoid outliers, then multiply by -1 to convert it to a liquidity measure. We define this measure as:

$$
L i q_{i, d}=-\log \left(1+\frac{\left|R_{i, d}\right|}{P_{i, d} V O_{i, d}}\right),
$$

where $R_{i, d}$ is the daily return of stock $i$ on day $d, P_{i, d}$ is the share price in local currency and $V O_{i, d}$ is the trading volume of the stock. 
First, we regress the liquidity measure for each stock on the lagged value of liquidity and days of the week in liquidity based on daily observations for each month (given as subscript $t$ ) by using the following equation:

$$
L i q_{i, t, d}=\alpha_{i, t} L i q_{i, d-1}+\sum_{n=1}^{5} \beta_{i, t}^{n} D_{n}+\omega_{i, t, d}
$$

where $D_{n}$ denotes five dummies for each day of the week. Second, we apply the residuals (innovations) from (2) to estimate the monthly commonality in liquidity measured by $R^{2}$ for each stock. We compute the commonality in liquidity from an equal weighted average of all commonality measures across firms in that country and obtain a monthly time-series of the commonality measure for each country via the equation below:

$$
\hat{\omega}_{i, t, d}=\alpha_{i, t}+\sum_{j=-1}^{1} \beta_{i, t}^{j} \hat{\omega}_{m, t, d+j}+\varepsilon_{i, t, d}
$$

where $\hat{\omega}_{m, t, d+j}$ is the residual on the value-weighted average of all stocks (e.g., a proxy for the market) in the same country within one month for the lead and lag in days. Similar to Chordia et al. (2000), we include one-day leading and lagging values of the value-weighted average of residuals of all stocks in the same country to capture any lagged adjustments in commonality. The regressions in Equation (3) generate a monthly time-series of the commonality in liquidity (e.g., $R_{\text {Amihud }}^{2}$ ) for each stock for each country. ${ }^{7}$ Because the value of the commonality measure $\left(R_{\text {Amihud }}^{2}\right)$ falls between zero and one, to be useful as a dependent variable, we use the logistic transformation $\ln \left[\frac{R_{\text {Amihud }}^{2}}{1-R_{\text {Amihud }}^{2}}\right] .{ }^{8}$

\subsection{Sources of Commonality in Liquidity}

In order to investigate the critical role of oil factors in explaining the variations in commonality in liquidity in equity across the global markets, we include various factors that have shown statistically significant effects on the commonality in equity in previous studies. The funding role that intermediaries play in the stock markets is arguably able to trigger the co-movements evident in stock market liquidity. Brunnermeier and Pedersen (2009) argued that although financial intermediaries, which may include specialists and other market makers, provide liquidity to stock market participants; they are at risk of forced liquidation of the securities that they hold as collateral. This risk increases during large market declines and high increases in volatility. Brunnermeier and Pedersen (2009) predicted that commonality in liquidity increases during large market declines and high market volatility. Hameed et al. (2010), using NYSE stocks, found a direct association between commonality in liquidity and large market declines and high market volatility. ${ }^{9}$ Globally, Karolyi et al. (2012) found evidence supporting this prediction using a sample of 40 countries. In addition, they incorporated several variables that may capture the time variations of funding constraints.

To consider the supply effect, we include the market returns and volatility in our regression equations. For each country, the market return is defined as the value-weighted average of the returns of individual stocks within the country. Following Karolyi et al. (2012), market volatility is calculated as the monthly standard deviation of the value-weighted market return multiplied by the square root of 22, representing the number of business days in a month. We include market condition variables that capture country-specific effects. Namely, we control for market liquidity and market turnover, defined as the value-weighted average of the monthly Amihud measure and the turnover of individual stocks within the country, respectively. US commercial paper spreads and local short-term interest rates are also included, as both variables indicate the level of credit constraints. We also add a time trend to test its significance because Karolyi et al. (2012) showed that a negative time trend in commonality in liquidity was statistically significant in about half of the countries in their sample.

The demand effect is a set of factors concerning how stock traders' activity can lead to co-movements in market liquidity. Besides the effect of market volatility on the supply of 
funding, as Coughenour and Saad (2004) and Vayanos (2004) argued, high market volatility may create correlated trading behavior, which, in turn, can trigger commonality in liquidity. Kamara et al. (2008) and Koch et al. (2016) found evidence supporting this hypothesis by observing a positive association between institutional trading and mutual fund ownership, respectively, with commonality in liquidity. To account for this effect, we use the measure of commonality in turnover to proxy for correlated trading activity, which is defined as:

$$
\operatorname{Turn}_{i, d}=\log \left(1+\frac{\text { VO }_{i, d}}{\text { Shares }_{i, y}}\right),
$$

where Shares $i, y$ is the number of shares of stock $i$ outstanding at the beginning of year $y$. Similar to $R_{\text {Amihud }}^{2}$, we estimate the residuals in Turnover for each stock based on daily observations for each month, creating a monthly time-series of residuals for each stock. We control for the lagged value of Turnover and days of the week in estimating the residuals and use those residuals to estimate the monthly measure of commonality in Turnover $\left(R_{\text {Turnover }}^{2}\right)$. As suggested by Karolyi et al. (2012), in order to ensure that $R_{\text {Turnover }}^{2}$ is orthogonal to the supply factors, as it may be correlated with funding constraints, we used the residuals from regressions of $R_{\text {Turnover }}^{2}$ on the supply-side factors, namely local short-term interest rates and US commercial papers for each country.

Two variables are included to control for the consequences of institutional and foreign ownership, as they may increase correlations in trading activity (Kamara et al. 2008). First, we include changes in exchange rate of local currencies relative to special drawing rights (SDR). This variable is obtained from international financial statistics (IFS) provided by the International Monetary Fund (IMF). As the local currency depreciates, foreign institutional investors are motivated to enter or increase their holdings in the foreign markets (Karolyi et al. 2012). Second, we add net percentage equity flows based on capital flows from and to the US, obtained from the Treasury International Capital (TIC) of the US Treasury Department. For each country, this variable is computed as the difference between the item: "Gross sales of foreign stock by foreigners to US residents" and the item: "Gross purchases of foreign stocks by foreigners from US residents" scaled by the sum of the two items. We also add a capital market openness measure, defined as the gross capital flow scaled by GDP for each country. In addition, we include the US sentiment index ${ }^{10}$ to account for investor sentiment, as it may prompt co-movements in liquidity through panic selling during times with high uncertainty (Hameed et al. 2010).

\section{Data and Preliminary Analysis}

\subsection{Sample}

Our sample comprises publicly traded firms from 50 countries and spans from January 1995 to December 2015. These countries include those in the East Asia and Pacific region (Australia, China, Hong Kong, Indonesia, Japan, South Korea, Malaysia, New Zealand, the Philippines, Singapore, Thailand, Taiwan, and Vietnam), the European region (Austria, Belgium, Czech Republic, Denmark, Finland, France, Germany, Greece, Ireland, Italy, the Netherlands, Norway, Poland, Portugal, Russia, Spain, Sweden, Switzerland, Turkey, and the United Kingdom), the Latin American region (Argentina, Brazil, Chile, Mexico, and Peru), the Middle East and North Africa region (Egypt, Israel, Kuwait, Qatar, Saudi Arabia, and the United Arab Emirates), the North America region (the US and Canada), the Southeast Asia region (Bangladesh, India, Pakistan, and Sri Lanka) and the Sub-Saharan Africa region (Nigeria).

According to the World Economic Outlook (2015), published by the IMF, 27 countries out of the 50 in our sample are classified as advanced economies, whereas 23 countries are classified as emerging markets and developing economies. Furthermore, our extended sample of countries contained 15 net oil-exporting countries, which include five members of the Organization of the Petroleum Exporting Countries (OPEC). Unlike previous studies, we extended the sample to cover major oil-exporting countries, particularly the members 
of OPEC, as they are essential in our research question. We limited our sample to these 50 countries because others lack sufficient data to construct the key variables in this study (e.g., trading volumes).

We obtained daily and annual data for the firms in our sample from Global Compustat. From these 50 countries, our final sample consisted of 36,930 firms with a starting date in January 1995 and ending in December 2015. We included all available firms that passed our screening process, including firms whose data ended before the latest date to avoid survivorship bias. We restricted the sample to stocks from the major exchanges in each market. For example, for the US, we used only the NYSE, as it is evident in the literature that the NYSE and NASDAQ are different in terms of trading volume definitions (Atkins and Dyl 1997). The observations included Chinese firms listed in both Shanghai and Shenzhen and Japanese firms listed in both Osaka and Tokyo. To avoid including firms more than once, we only included firm observations that are reported in the local currency. We excluded firms with special features such as depositary receipts, real estate investment trusts, preferred stocks, and investment funds. The following filters were also applied: we excluded days on which $90 \%$ or more of the stocks listed on a given exchange had a return equal to zero, considering them to be non-trading days; stock-month observations if the number of zero-return days was more than $80 \%$ in a given month, considering it to be a non-traded stock for that month; and stock-day observations with a daily return in the top or the bottom $0.1 \%$ of the cross-sectional distribution within a country to avoid outliers. ${ }^{11}$

One-month crude oil futures prices traded on the NYMEX were obtained from the US Energy Information Administration (EIA). In addition, annual data of crude oil production, consumption, exports, and imports for each country were obtained from the EIA. We collected the annual GDP (constant 2005 US dollars) from the World Bank and the exchange rates and interest rates from the IFS of the IMF. The US interest rates were acquired from the Federal Reserve. We downloaded data for international capital flows from TIC and the US Sentiment Index from Jeff Wurgler's website. Table A1 in Appendix A provides a detailed definition of the variables used and the data sources.

\subsection{Descriptive Statistics}

Table 1 presents the descriptive statistics of the macroeconomic and oil-related variables for each country. We sorted countries by descending order on the basis of their oil sensitivity ratio. Most importantly, the table presents the oil sensitivity ratio which is one of the main inputs in our estimation and analysis. The country with the highest ratio of oil sensitivity was Saudi Arabia, followed by the other four OPEC members, whereas the lowest five were Hong Kong, Taiwan, the United Kingdom, Brazil, and Australia, in order. This finding is unsurprising, since Saudi Arabia is considered the largest exporter of crude oil with an average of 6761.5 thousand barrels per day from 1995 to 2015 compared with an average of 413.3 thousand of barrels per day for the remaining 49 countries over the same period. Furthermore, the oil production of the five OPEC members included in our sample accounted for more than $24 \%$ of global oil production in 2015. 


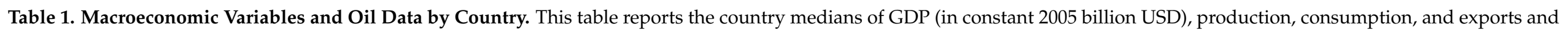

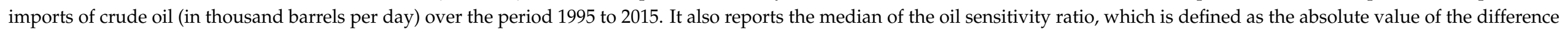

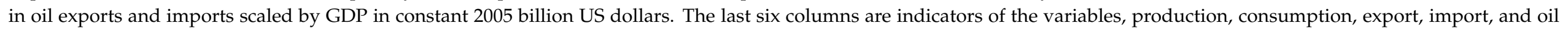

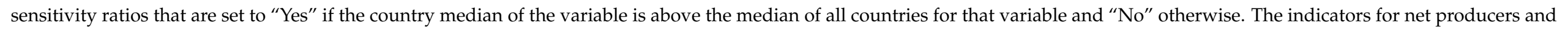
net exporters are reported as "Yes" if the country is a net producer or net exporter by median, respectively, and "No" otherwise.

\begin{tabular}{|c|c|c|c|c|c|c|c|c|c|c|c|c|c|}
\hline Country & GDP & Prod. & Cons. & Exports & Imports & $\begin{array}{c}\text { Oil Sens. } \\
\text { Ratio }\end{array}$ & $\begin{array}{l}\text { High } \\
\text { Prod. }\end{array}$ & $\begin{array}{l}\text { High } \\
\text { Cons. }\end{array}$ & $\begin{array}{c}\text { High } \\
\text { Export }\end{array}$ & $\begin{array}{c}\text { High } \\
\text { Import }\end{array}$ & $\begin{array}{l}\text { High Oil } \\
\text { Sens. }\end{array}$ & $\begin{array}{c}\text { Net } \\
\text { Producer }\end{array}$ & $\begin{array}{c}\text { Net } \\
\text { Exporter }\end{array}$ \\
\hline Saudi Arabia & 314.18 & $10,195.76$ & 1829.50 & 6693.25 & 0.00 & 21.30 & Yes & Yes & Yes & No & Yes & Yes & Yes \\
\hline Nigeria & 105.92 & 2236.80 & 281.13 & 2092.27 & 0.00 & 19.75 & Yes & Yes & Yes & No & Yes & Yes & Yes \\
\hline$U A E$ & 168.99 & 2713.79 & 469.59 & 2122.80 & 0.00 & 12.56 & Yes & Yes & Yes & No & Yes & Yes & Yes \\
\hline Qatar & 60.80 & 1090.35 & 77.36 & 683.23 & 0.00 & 11.24 & Yes & No & Yes & No & Yes & Yes & Yes \\
\hline Norway & 297.15 & 3062.36 & 221.55 & 2692.84 & 18.58 & 9.00 & Yes & No & Yes & No & Yes & Yes & Yes \\
\hline Singapore & 121.46 & 9.90 & 776.82 & 0.70 & 975.04 & 8.02 & No & Yes & No & Yes & Yes & No & No \\
\hline Thailand & 180.77 & 259.84 & 961.01 & 37.71 & 786.06 & 4.14 & Yes & Yes & Yes & Yes & Yes & No & No \\
\hline S. Korea & 856.13 & 17.08 & 2165.25 & 1.99 & 2382.05 & 2.78 & No & Yes & No & Yes & Yes & No & No \\
\hline Philippines & 99.23 & 19.20 & 330.52 & 0.00 & 244.60 & 2.46 & Yes & Yes & No & Yes & Yes & No & No \\
\hline India & 792.38 & 826.41 & 2488.29 & 0.00 & 1850.33 & 2.34 & Yes & Yes & No & Yes & Yes & No & No \\
\hline Mexico & 838.96 & 3441.01 & 2069.42 & 1707.55 & 8.59 & 2.03 & Yes & Yes & Yes & No & Yes & Yes & Yes \\
\hline Netherlands & 659.44 & 49.88 & 933.26 & 23.22 & 1282.84 & 1.91 & No & No & Yes & Yes & Yes & No & No \\
\hline Greece & 222.42 & 7.11 & 401.30 & 0.10 & 409.80 & 1.84 & No & Yes & No & Yes & Yes & No & No \\
\hline Belgium & 376.02 & 11.34 & 625.27 & 62.02 & 717.84 & 1.74 & No & No & Yes & Yes & Yes & No & No \\
\hline Sri Lanka & 23.69 & -0.52 & 79.63 & 0.00 & 40.33 & 1.70 & No & Yes & No & Yes & Yes & No & No \\
\hline Chile & 118.44 & 17.16 & 262.20 & 0.00 & 192.22 & 1.62 & No & Yes & No & Yes & Yes & No & No \\
\hline Malaysia & 136.70 & 766.00 & 493.95 & 365.04 & 147.80 & 1.59 & Yes & Yes & Yes & Yes & Yes & Yes & Yes \\
\hline Egypt & 87.61 & 738.85 & 584.31 & 139.15 & 0.00 & 1.59 & Yes & Yes & Yes & No & Yes & Yes & Yes \\
\hline Portugal & 193.39 & 3.97 & 305.36 & 0.00 & 270.85 & 1.40 & No & No & No & Yes & Yes & No & No \\
\hline Pakistan & 102.20 & 63.85 & 358.60 & 1.55 & 144.68 & 1.40 & Yes & Yes & Yes & Yes & Yes & No & No \\
\hline Finland & 195.15 & 9.16 & 212.15 & 0.00 & 234.12 & 1.20 & No & No & No & Yes & Yes & No & No \\
\hline Poland & 297.31 & 26.53 & 442.40 & 4.28 & 359.36 & 1.19 & No & No & No & Yes & No & No & No \\
\hline Sweden & 372.99 & 4.03 & 365.02 & 8.97 & 408.27 & 1.07 & No & No & Yes & Yes & No & No & No \\
\hline Spain & 1098.61 & 28.33 & 1454.26 & 0.00 & 1165.66 & 1.06 & No & No & No & Yes & No & No & No \\
\hline Turkey & 449.45 & 53.01 & 658.54 & 0.00 & 470.70 & 1.05 & No & No & No & Yes & No & No & No \\
\hline
\end{tabular}


Table 1. Cont.

\begin{tabular}{|c|c|c|c|c|c|c|c|c|c|c|c|c|c|}
\hline Country & GDP & Prod. & Cons. & Exports & Imports & $\begin{array}{c}\text { Oil Sens. } \\
\text { Ratio }\end{array}$ & $\begin{array}{l}\text { High } \\
\text { Prod. }\end{array}$ & $\begin{array}{l}\text { High } \\
\text { Cons. }\end{array}$ & $\begin{array}{l}\text { High } \\
\text { Export }\end{array}$ & $\begin{array}{l}\text { High } \\
\text { Import }\end{array}$ & $\begin{array}{l}\text { High Oil } \\
\text { Sens. }\end{array}$ & $\begin{array}{c}\text { Net } \\
\text { Producer }\end{array}$ & $\begin{array}{c}\text { Net } \\
\text { Exporter }\end{array}$ \\
\hline Italy & 1802.45 & 147.15 & 1831.73 & 16.68 & 1813.94 & 1.00 & No & No & No & Yes & No & No & No \\
\hline Japan & 4446.03 & 122.23 & 5293.08 & 0.00 & 4275.99 & 0.96 & No & No & No & No & No & No & No \\
\hline Peru & 72.73 & 117.49 & 159.58 & 20.33 & 87.05 & 0.92 & Yes & Yes & Yes & Yes & No & No & No \\
\hline Argentina & 214.77 & 811.80 & 543.18 & 206.17 & 14.20 & 0.89 & Yes & Yes & Yes & No & No & Yes & Yes \\
\hline USA & $12,438.81$ & 9028.10 & $19,508.65$ & 127.45 & $10,267.64$ & 0.82 & Yes & No & No & No & No & No & No \\
\hline Canada & 1111.31 & 3104.97 & 2192.24 & 1722.36 & 849.22 & 0.79 & Yes & Yes & Yes & No & No & Yes & Yes \\
\hline Germany & 2848.20 & 135.33 & 2663.63 & 14.62 & 2125.58 & 0.74 & No & No & No & No & No & No & No \\
\hline Indonesia & 278.17 & 1214.35 & 1187.62 & 504.07 & 307.32 & 0.71 & Yes & Yes & Yes & Yes & No & Yes & Yes \\
\hline New Zealand & 109.22 & 47.82 & 147.90 & 27.62 & 97.62 & 0.64 & Yes & No & Yes & No & No & No & No \\
\hline Austria & 306.18 & 26.64 & 268.07 & 0.47 & 166.77 & 0.54 & No & No & No & No & No & No & No \\
\hline Denmark & 255.21 & 296.55 & 190.54 & 188.79 & 79.03 & 0.43 & Yes & No & Yes & No & No & Yes & Yes \\
\hline Bangladesh & 66.64 & 5.05 & 83.32 & 0.00 & 25.02 & 0.38 & No & No & No & No & No & No & No \\
\hline Ireland & 194.60 & -0.24 & 168.99 & 0.00 & 63.04 & 0.32 & No & No & No & No & No & No & No \\
\hline Switzerland & 398.52 & 2.60 & 267.34 & 0.00 & 101.07 & 0.25 & No & No & No & No & No & No & No \\
\hline Australia & 666.39 & 616.96 & 934.72 & 275.75 & 418.79 & 0.21 & Yes & No & Yes & No & No & No & No \\
\hline UK & 2320.06 & 100.09 & 1762.40 & 1436.75 & 1111.29 & 0.14 & No & No & Yes & No & No & No & Yes \\
\hline Taiwan & $10,587.58$ & 9.48 & 932.42 & 0.00 & 835.50 & 0.08 & No & No & No & No & No & No & No \\
\hline Hong Kong & 171.63 & 0.00 & 295.83 & 0.00 & 0.00 & 0.00 & No & No & No & No & No & No & No \\
\hline Mean & 1055.99 & 1169.25 & 1423.94 & 551.76 & 793.85 & 3.12 & & & & & & & \\
\hline Median & 278.17 & 100.09 & 497.06 & 14.62 & 270.85 & 1.19 & & & & & & & \\
\hline
\end{tabular}


A country is a net exporter if, on average, it exports more crude oil than it imports, and it is highly oil-sensitive if its oil sensitivity ratio is above the median of the oil sensitivity ratios of all countries. Five of the net exporters in our sample, namely Argentina, Canada, Indonesia, Denmark, and the United Kingdom, have oil sensitive ratios lower than the median of all countries. If we examine the earliest data available for 2014 and 2015, the average oil exports as a percentage of merchandise exports in the five OPEC members included in our sample is about $79 \%$, whereas this proportion is $2.6 \%, 21.4 \%, 29.2 \%$, $4.9 \%$, and $7.6 \%$ for Argentina, Canada, Indonesia, Denmark, and the United Kingdom, respectively. This clearly distinguishes the two groups of net exporters in terms of how their economies are dependent on oil.

Table 2 presents information on the firms' market values and commonality measures for all 50 countries. For each country, we show the start and the end date of the data, the number of firms included, the number of monthly observations, a net exporter indicator, and an oil sensitivity indicator. In addition, we show the value-weighted averages of market returns, market turnover, and market liquidity along with market volatility, which we define as the monthly standard deviation of the value-weighted market return multiplied by the square root of 22 (the number of business days in a month). Additionally, Table 2 shows the mean and the standard deviation of the commonality in liquidity measure $\left(R_{\text {Amihud }}^{2}\right)$ and the commonality in turnover $\left(R_{\text {Turnover }}^{2}\right)$. The countries with the largest number of firms in our sample are Japan, India, and Australia with 3019, 2958, and 2709 firms, respectively. Conversely, countries with the lowest number of firms in our sample are Qatar, the United Arab Emirates, and Ireland with 45, 66, and 109 firms, respectively. The number of firms included in our sample is 36,930 firms, with more than 2.3 million monthly observations.

The summary statistics of market conditions and the commonality variables are qualitatively similar to those documented in the paper of Karolyi et al. (2012). However, quantitative differences are expected, since we expanded the timeframe to cover the most recent 6 years and because the source of the financial data we used are different $^{12}$. Table 1 shows that the monthly market return of all countries is positive except for Greece, which may be influenced by the government debt crisis that began in late 2009 . Similar to Karolyi et al. (2012), our results document that France, the Netherlands, and Switzerland have the lowest commonality in liquidity ratios, whereas China has the highest commonality in liquidity ratio by far.

Figure 1 presents the time path of oil futures prices (Graph A), the average commonality in liquidity measure $\left(R_{\text {Amihud }}^{2}\right)$ of all countries (Graph B), highly oil-sensitive countries (Graph C), less oil-sensitive countries (Graph D), highly oil-sensitive net exporter countries (Graph E), and highly oil-sensitive net importer countries (Graph F). In Graph A, we can observe three different oil shock episodes during our sample period. The first episode appears to be driven by the oil demand shock during the East Asian Financial Crisis in 1997 and 1998, which caused the price of oil to reach below \$12 a barrel in December 1998 from a price of more than $\$ 25$ a barrel in January 1997. Secondly, an oil spike, which was followed by a dramatic oil price drop, seemed to be caused by the growing demand and stagnant supply during the global financial crisis from the beginning of 2007 to the middle of 2008. The price of oil soared to more than $\$ 133$ a barrel in June 2008 compared with less than $\$ 55$ a barrel in January 2007. The collapse in demand in the aftermath of the global financial crisis in 2007-2008 caused the price of oil to reach below \$42 per barrel in January 2009 (Rogoff 2016). More recently, a third oil shock episode relates to the oil price drop that started in June 2014, driven by a mix of supply and demand factors. The slowing growth in emerging markets, the surprise increase in oil production and OPEC's decision to maintain their production level of 30 million barrels per day in spite of a perceived excess supply caused the oil price to plunge to less than $\$ 38$ a barrel from its peak of more than $\$ 105$ a barrel in June 2014 (Arezki and Blanchard 2014; Kilian 2015). 


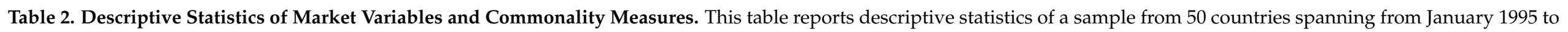

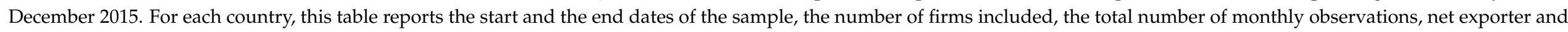

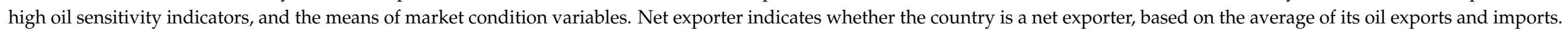

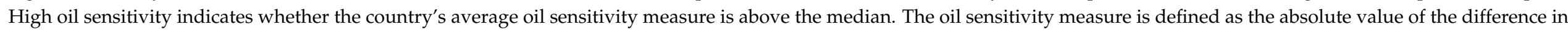

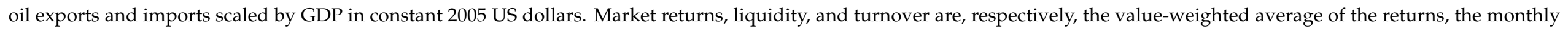

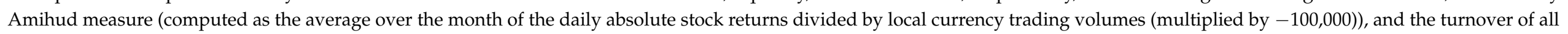

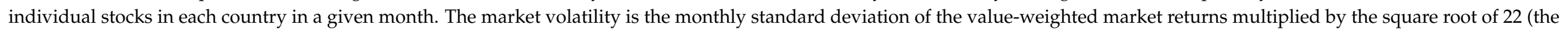

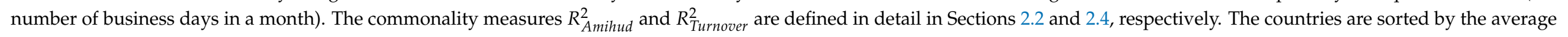
oil sensitivity measure: the first country has the highest average oil sensitivity, and the last country has the lowest.

\begin{tabular}{|c|c|c|c|c|c|c|c|c|c|c|c|c|c|c|}
\hline \multirow{2}{*}{ Country } & \multirow{2}{*}{$\begin{array}{l}\text { Start } \\
\text { Date }\end{array}$} & \multirow{2}{*}{$\begin{array}{l}\text { End } \\
\text { Date }\end{array}$} & \multirow{2}{*}{$\begin{array}{c}\text { No. } \\
\text { Firms }\end{array}$} & \multirow{2}{*}{ No. Obs } & \multirow{2}{*}{$\begin{array}{c}\text { Net } \\
\text { Exporter }\end{array}$} & \multirow{2}{*}{$\begin{array}{l}\text { High } \\
\text { Sens. }\end{array}$} & \multirow{2}{*}{$\begin{array}{l}\text { Market } \\
\text { Return }\end{array}$} & \multirow{2}{*}{$\begin{array}{c}\text { Market } \\
\text { Volatility }\end{array}$} & \multirow{2}{*}{$\begin{array}{c}\text { Market } \\
\text { Turnover }\end{array}$} & \multirow{2}{*}{$\begin{array}{c}\text { Market } \\
\text { Liquidity }\end{array}$} & \multicolumn{2}{|c|}{$R_{A m i h u d}^{2}$} & \multicolumn{2}{|c|}{$R_{\text {Turnover }}^{2}$} \\
\hline & & & & & & & & & & & Mean & Stdev & Mean & Stdev \\
\hline Saudi Arabia & 200203 & 201512 & 178 & 13,813 & Yes & Yes & 1.1157 & 6.7902 & 0.3095 & -0.0068 & 28.2580 & 11.6673 & 25.5178 & 5.8596 \\
\hline Nigeria & 200008 & 201512 & 225 & 10,188 & Yes & Yes & 1.1973 & 4.7649 & 0.0413 & -0.0848 & 22.1176 & 4.0975 & 22.4787 & 4.0566 \\
\hline Kuwait & 200403 & 201512 & 213 & 11,260 & Yes & Yes & 0.1994 & 5.0608 & 0.1254 & -35.8040 & 22.9613 & 5.3339 & 24.1188 & 4.3839 \\
\hline$U A E$ & 200602 & 201512 & 66 & 2138 & Yes & Yes & 0.8630 & 6.0476 & 0.0540 & -0.8220 & 21.7511 & 5.4340 & 26.9081 & 5.3914 \\
\hline Qatar & 200807 & 201512 & 45 & 2009 & Yes & Yes & 0.6216 & 3.6692 & 0.0490 & -0.0490 & 21.3836 & 4.2967 & 27.5325 & 5.4679 \\
\hline Norway & 199501 & 201512 & 389 & 24,369 & Yes & Yes & 0.6943 & 5.7213 & 0.2346 & -0.2314 & 20.5912 & 3.3961 & 21.8519 & 3.0381 \\
\hline Singapore & 199601 & 201512 & 845 & 69,742 & No & Yes & 0.4450 & 4.9182 & 0.1389 & -1.9846 & 20.6737 & 2.6435 & 22.9705 & 4.4844 \\
\hline Russia & 200205 & 201310 & 220 & 1926 & Yes & Yes & 1.0519 & 12.4206 & 0.0070 & -3.9941 & 24.2521 & 5.4795 & 26.7513 & 5.7619 \\
\hline Thailand & 199601 & 201512 & 804 & 72,448 & No & Yes & 0.4582 & 6.9307 & 0.2055 & -0.3489 & 20.2981 & 3.0001 & 24.5858 & 5.6111 \\
\hline S. Korea & 199506 & 201512 & 1923 & 104,102 & No & Yes & 0.4676 & 7.3797 & 0.4811 & -0.0014 & 20.8478 & 4.7844 & 23.4393 & 4.5777 \\
\hline Philippines & 199502 & 201512 & 293 & 25,369 & No & Yes & 0.8719 & 5.9233 & 0.0642 & -0.4585 & 20.7214 & 2.9601 & 22.6049 & 3.7564 \\
\hline India & 199707 & 201512 & 2958 & 125,343 & No & Yes & 0.2710 & 6.9768 & 0.1248 & -6.5485 & 20.6784 & 4.7163 & 20.3958 & 2.7369 \\
\hline Mexico & 199608 & 201512 & 212 & 12,166 & Yes & Yes & 1.2440 & 5.6921 & 0.1085 & -0.1196 & 19.9240 & 4.5731 & 27.1433 & 5.6046 \\
\hline Netherlands & 199501 & 201512 & 281 & 27,464 & No & Yes & 0.6277 & 5.4662 & 0.3630 & -0.5017 & 19.5229 & 2.8846 & 23.0773 & 5.2589 \\
\hline Greece & 199501 & 201512 & 388 & 42,244 & No & Yes & -0.1766 & 8.5273 & 0.1346 & -19.6495 & 21.8384 & 5.2175 & 23.1778 & 5.0222 \\
\hline Belgium & 199510 & 201402 & 283 & 21,047 & No & Yes & 0.4403 & 4.9198 & 0.0985 & -1.0528 & 20.3562 & 5.3907 & 23.1655 & 3.7524 \\
\hline Sri Lanka & 200312 & 201512 & 314 & 19,888 & No & Yes & 1.5410 & 5.2653 & 0.0428 & -7.5016 & 21.8716 & 4.8345 & 22.0859 & 3.8997 \\
\hline S. Africa & 199607 & 201512 & 845 & 46,710 & No & Yes & 0.9521 & 4.9274 & 0.1754 & -0.8155 & 20.2157 & 3.0588 & 22.1942 & 4.3884 \\
\hline Chile & 199609 & 201512 & 226 & 12,430 & No & Yes & 0.9843 & 4.0317 & 0.0505 & -0.0055 & 20.5073 & 3.4411 & 23.5628 & 4.2077 \\
\hline Malaysia & 199601 & 201512 & 1135 & 48,875 & Yes & Yes & 0.4170 & 4.5524 & 0.0860 & -2.6582 & 22.0951 & 4.8090 & 30.2395 & 11.6070 \\
\hline Egypt & 200210 & 201512 & 224 & 14,741 & Yes & Yes & 1.5340 & 7.7962 & 0.1423 & -0.5531 & 23.4365 & 8.0351 & 24.1859 & 4.7927 \\
\hline Portugal & 199608 & 201512 & 125 & 8338 & No & Yes & 0.2595 & 4.9455 & 0.1668 & -1.8563 & 20.6244 & 3.9424 & 24.4918 & 5.6689 \\
\hline Pakistan & 199505 & 201512 & 534 & 35,668 & No & Yes & 1.2965 & 6.7769 & 0.4932 & -2.6292 & 21.5395 & 5.1790 & 23.6647 & 4.1605 \\
\hline
\end{tabular}


Table 2. Cont.

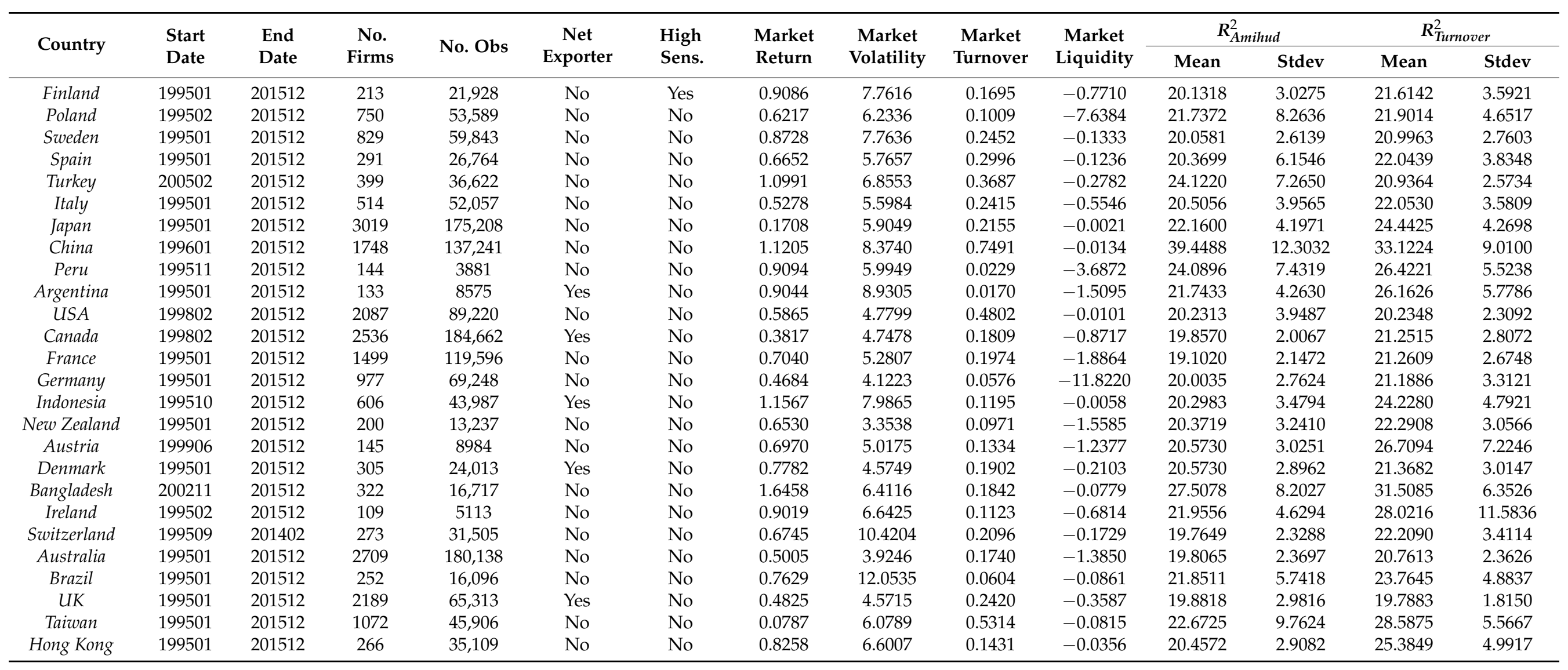


J. Risk Financial Manas. 2021, 14, 372

15 of 33

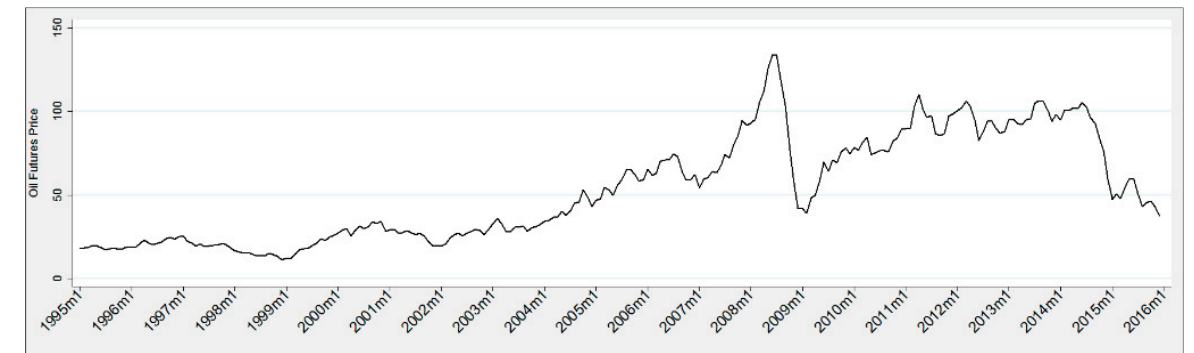

(A) Oil futures prices

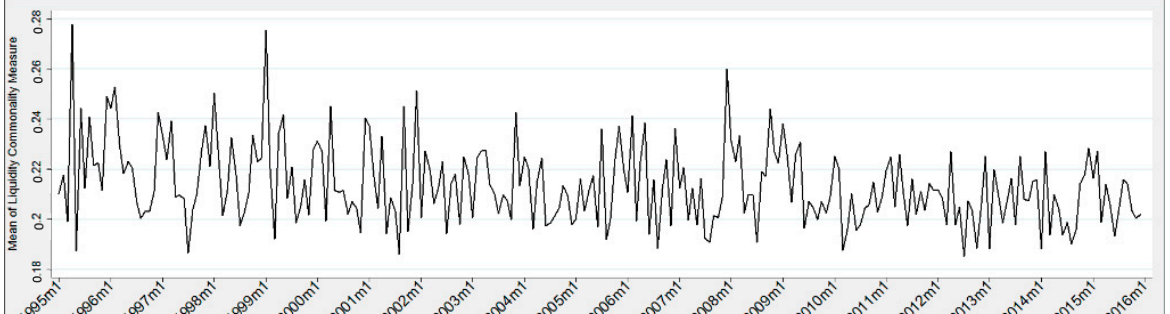

(C) Highly oil-sensitive countries

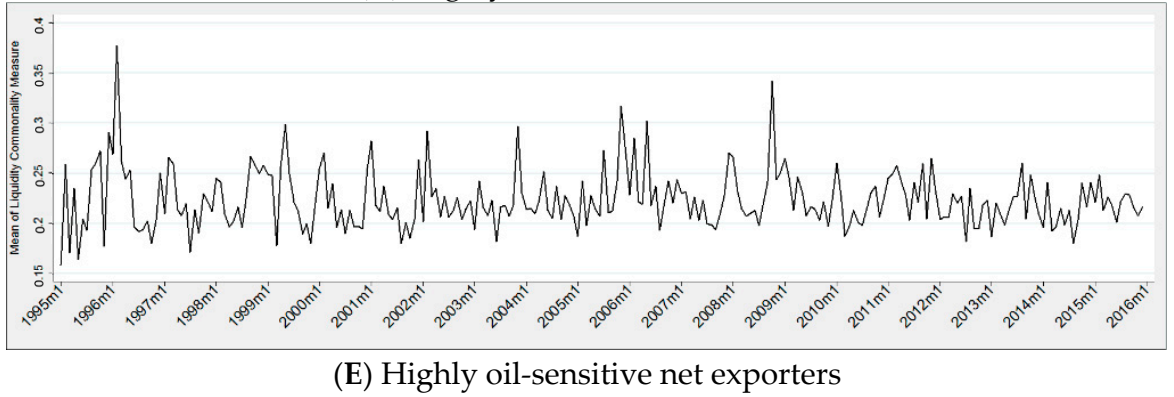

(E) Highly oil-sensitive net exporters

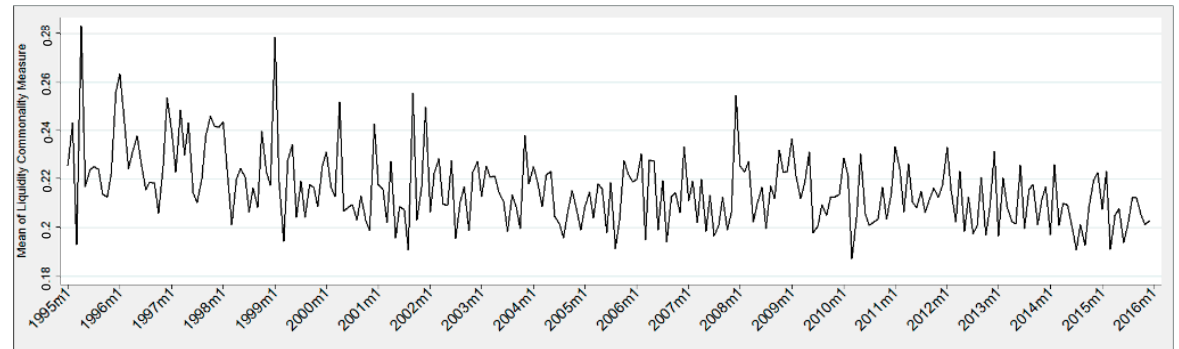

(B) All countries

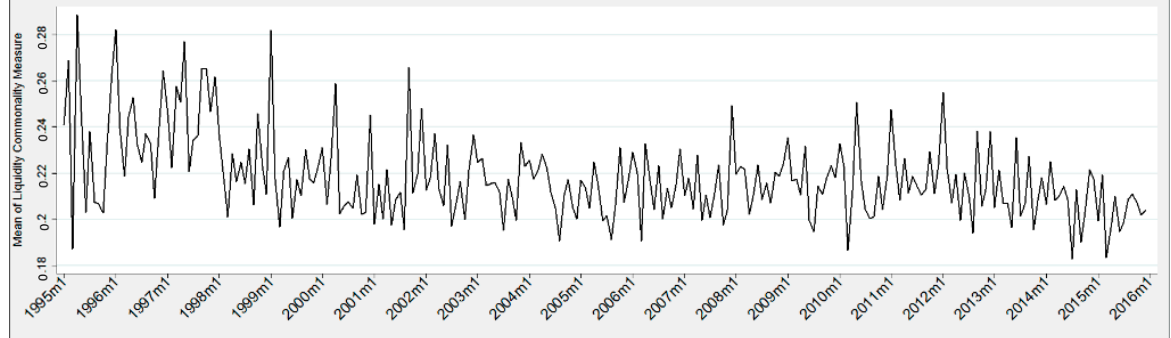

(D) Less oil-sensitive countries

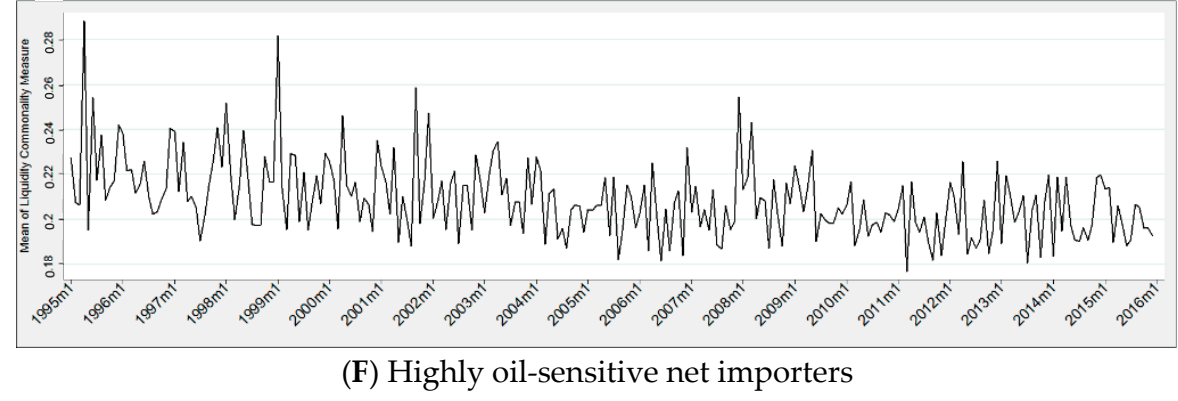

Figure 1. These graphs show the time series spanning from January 1995 to December 2015 of oil futures prices (A) and the average liquidity commonality measure ( $R_{\text {Amihud }}^{2}$ ) of all countries (B), highly oil-sensitive countries (C), less oil-sensitive countries (D), highly oil-sensitive net exporters (E), and highly oil-sensitive net importers (F). The liquidity commonality measure is defined in detail in Section 2.2. 
Table 3 presents the pairwise correlations of the measure of commonality in liquidity $\left(R_{\text {Amihud }}^{2}\right)$ across countries. Panel A shows the coefficients of the correlations among the countries in the highly oil-sensitive group and Panel B shows the coefficients of the correlation between the countries in the highly oil-sensitive group and those in the less oil-sensitive group. Out of the 25 highly oil-sensitive countries, 18 countries show a higher percentage of statistically significant correlations when we compare the correlation coefficients between them and the other countries in their group as opposed to the countries in the less sensitive group. In addition, 8 out of 10 highly oil-sensitive net exporter countries show improvements in the percentage of significant correlations when we compare their correlations with the highly oil-sensitive countries as opposed to the less sensitive countries. Overall, Table 3 documents positive and statistically significant correlations in commonality in liquidity across countries, which indicate that underlying common factors cause their commonality in liquidity levels to co-move. The presence of significant correlations among countries grouped by their sensitivity to the oil market allows us to show the importance of this classification and warrants further analysis. In the next section, we use a regression model that includes oil market returns and volatility as the common underlying factors determining the commonality in liquidity across the countries in our sample. The specification also controls for other common factors that have been mentioned in the relevant literature to explain variations in commonality in liquidity across countries. Controlling the explanatory variables of commonality in liquidity is essential to investigate the robust effect of oil factors and to avoid omitted variable biases. 


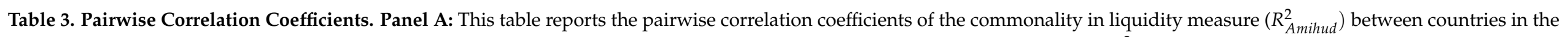

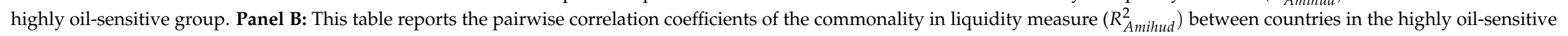
and the less oil-sensitive groups. Bold font refers to a statistical significance at the $1 \%$ level.

\begin{tabular}{|c|c|c|c|c|c|c|c|c|c|c|c|c|c|c|c|c|c|c|c|c|c|c|c|c|c|}
\hline \multicolumn{26}{|c|}{ (A) } \\
\hline & 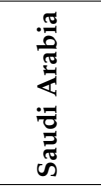 & $\begin{array}{l}\stackrel{\pi}{\tilde{J}} \\
\stackrel{.0}{\mathrm{D}} \\
\ddot{Z}\end{array}$ & 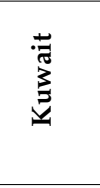 & 峁 & ă & $\begin{array}{l}\text { ते } \\
\text { ż } \\
\text { Z }\end{array}$ & 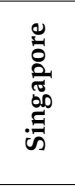 & 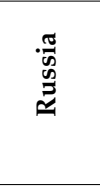 & 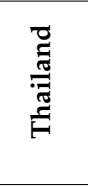 & 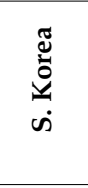 & 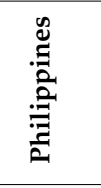 & : & & 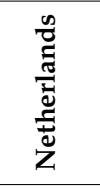 & 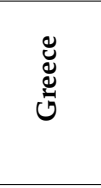 & $\frac{\Xi}{0.00}$ & 胥 & $\begin{array}{l}\overline{\mathscr{g}} \\
\stackrel{\tilde{g}}{\mathscr{\omega}}\end{array}$ & 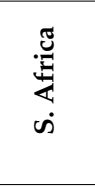 & $\stackrel{0}{\tilde{z}}$ & $\frac{\substack{\frac{\pi}{n} \\
\frac{\pi}{\pi}}}{\sum^{\pi}}$ & 营 & 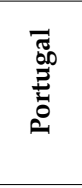 & 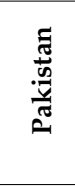 & 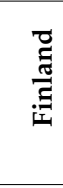 \\
\hline $\begin{array}{c}\text { Saudi } \\
\text { Arabia }\end{array}$ & 1.00 & & & & & & & & & & & & & & & & & & & & & & & & \\
\hline Nigeria & 0.17 & 1.00 & & & & & & & & & & & & & & & & & & & & & & & \\
\hline Kuwait & 0.24 & 0.27 & 1.00 & & & & & & & & & & & & & & & & & & & & & & \\
\hline Qatar & 0.06 & 0.05 & 0.37 & 0.16 & 1.00 & & & & & & & & & & & & & & & & & & & & \\
\hline Norway & -0.17 & 0.23 & 0.11 & -0.03 & -0.10 & 1.00 & & & & & & & & & & & & & & & & & & & \\
\hline Singapore & -0.01 & 0.20 & 0.07 & 0.33 & -0.17 & 0.24 & 1.00 & & & & & & & & & & & & & & & & & & \\
\hline Russia & 0.08 & 0.01 & 0.08 & -0.02 & N/A & -0.13 & 0.04 & 1.00 & & & & & & & & & & & & & & & & & \\
\hline Thailand & 0.01 & 0.15 & -0.01 & -0.03 & -0.12 & 0.16 & 0.17 & -0.07 & 1.00 & & & & & & & & & & & & & & & & \\
\hline S. Korea & -0.07 & 0.13 & -0.04 & -0.06 & 0.03 & 0.17 & 0.17 & 0.06 & 0.09 & 1.00 & & & & & & & & & & & & & & & \\
\hline Philippines & -0.05 & 0.16 & 0.11 & -0.07 & 0.13 & 0.31 & 0.16 & -0.05 & 0.09 & 0.06 & 1.00 & & & & & & & & & & & & & & \\
\hline India & 0.10 & 0.10 & 0.06 & 0.08 & -0.15 & 0.13 & 0.12 & 0.14 & 0.02 & -0.02 & 0.03 & 1.00 & & & & & & & & & & & & & \\
\hline Mexico & -0.07 & 0.11 & 0.07 & -0.04 & 0.20 & 0.17 & 0.10 & 0.17 & 0.00 & 0.09 & 0.17 & 0.23 & 1.00 & & & & & & & & & & & & \\
\hline Netherlands & 0.18 & 0.08 & 0.00 & 0.01 & -0.10 & 0.21 & 0.18 & 0.00 & 0.16 & 0.23 & 0.19 & 0.14 & 0.08 & 1.00 & & & & & & & & & & & \\
\hline Sri Lanka & -0.10 & 0.14 & 0.04 & -0.06 & -0.09 & 0.28 & 0.17 & -0.06 & 0.17 & 0.01 & 0.14 & 0.04 & 0.03 & 0.21 & 0.30 & 0.14 & 1.00 & & & & & & & & \\
\hline Israel & 0.09 & 0.14 & 0.02 & 0.07 & 0.04 & 0.20 & 0.16 & 0.05 & 0.06 & 0.08 & 0.09 & 0.02 & 0.03 & 0.03 & 0.03 & 0.07 & 0.14 & 1.00 & & & & & & & \\
\hline S. Africa & -0.05 & 0.15 & 0.16 & 0.03 & -0.18 & 0.28 & 0.15 & -0.01 & 0.21 & 0.23 & 0.10 & 0.02 & 0.22 & 0.31 & 0.23 & 0.15 & 0.24 & 0.03 & 1.00 & & & & & & \\
\hline Chile & -0.10 & 0.08 & 0.02 & -0.03 & -0.02 & 0.12 & 0.14 & 0.10 & -0.05 & 0.18 & 0.12 & 0.06 & 0.04 & 0.01 & -0.01 & 0.09 & 0.04 & 0.13 & 0.05 & 1.00 & & & & & \\
\hline Malaysia & -0.05 & 0.13 & 0.15 & 0.20 & 0.03 & 0.13 & 0.51 & 0.25 & 0.15 & 0.24 & 0.00 & 0.13 & 0.11 & 0.15 & 0.18 & 0.24 & 0.19 & 0.21 & 0.14 & 0.10 & 1.00 & & & & \\
\hline Egypt & -0.07 & 0.03 & 0.06 & 0.20 & 0.19 & -0.06 & 0.07 & 0.03 & -0.09 & -0.04 & -0.02 & -0.03 & -0.08 & -0.02 & 0.07 & -0.03 & 0.06 & -0.02 & -0.07 & 0.04 & 0.11 & 1.00 & & & \\
\hline Portugal & -0.08 & 0.07 & -0.02 & 0.05 & 0.08 & 0.24 & 0.09 & -0.14 & 0.11 & 0.07 & 0.13 & 0.04 & 0.01 & 0.12 & 0.08 & 0.15 & 0.17 & 0.13 & 0.24 & 0.11 & 0.22 & 0.06 & 1.00 & & \\
\hline Pakistan & -0.09 & 0.12 & 0.06 & 0.13 & -0.10 & 0.08 & 0.06 & 0.08 & 0.11 & 0.22 & -0.02 & 0.09 & 0.29 & -0.12 & -0.01 & 0.13 & -0.08 & 0.05 & 0.16 & 0.23 & 0.07 & -0.02 & 0.00 & 1.00 & \\
\hline Finland & 0.07 & 0.07 & 0.16 & 0.10 & -0.05 & 0.26 & 0.15 & 0.20 & 0.26 & 0.18 & 0.28 & 0.06 & 0.10 & 0.29 & 0.15 & 0.15 & 0.22 & 0.19 & 0.27 & 0.11 & 0.07 & -0.08 & 0.14 & 0.18 & 1.00 \\
\hline Average & 0.00 & 0.12 & 0.10 & 0.05 & 0.01 & 0.13 & 0.14 & 0.03 & 0.07 & 0.09 & 0.09 & 0.06 & 0.09 & 0.11 & 0.06 & 0.10 & 0.10 & 0.09 & 0.13 & 0.07 & 0.15 & 0.01 & 0.09 & 0.07 & 0.15 \\
\hline $\begin{array}{l}\text { \% Sig. } \\
\text { Corr. }\end{array}$ & $17 \%$ & $29 \%$ & $17 \%$ & $17 \%$ & $4 \%$ & $71 \%$ & $58 \%$ & $0 \%$ & $33 \%$ & $38 \%$ & $29 \%$ & $13 \%$ & $21 \%$ & $50 \%$ & $25 \%$ & $29 \%$ & $38 \%$ & $17 \%$ & $58 \%$ & $13 \%$ & $50 \%$ & $4 \%$ & $29 \%$ & $21 \%$ & $54 \%$ \\
\hline
\end{tabular}


Table 3. Cont.

\begin{tabular}{|c|c|c|c|c|c|c|c|c|c|c|c|c|c|c|c|c|c|c|c|c|c|c|c|c|c|}
\hline \multicolumn{26}{|c|}{ (B) } \\
\hline & 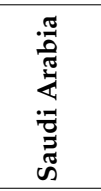 & \begin{tabular}{l}
$\stackrel{\pi}{\tilde{J}}$ \\
$\stackrel{.0}{Z}$ \\
\hdashline
\end{tabular} & 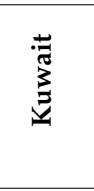 & 恧 & ă & $\begin{array}{l}\text { ते } \\
\text { Ż̀ }\end{array}$ & 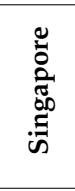 & 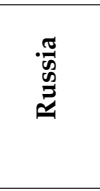 & 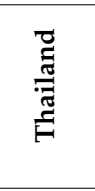 & $\begin{array}{l}\tilde{J} \\
\dot{0} \\
\dot{a} \\
\dot{\omega}\end{array}$ & 总 & 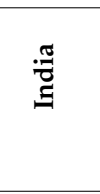 & $\frac{\stackrel{8}{x}}{\sum_{\Sigma}^{0}}$ & 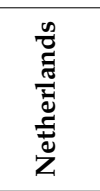 & 芯 & $\underset{D}{\stackrel{5}{\sigma 0}}$ & & 导 & 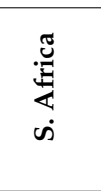 & : & $\frac{\frac{\pi}{n}}{\sum^{\frac{\pi}{\pi}}}$ & 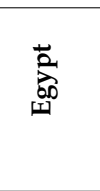 & 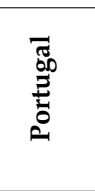 & 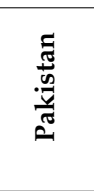 & 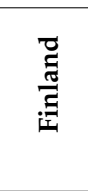 \\
\hline Poland & -0.11 & 0.28 & 0.02 & 0.08 & -0.17 & 0.16 & 0.09 & 0.13 & 0.12 & 0.22 & 0.10 & 0.07 & 0.03 & 0.15 & 0.05 & 0.23 & 0.25 & 0.13 & 0.10 & 0.09 & 0.15 & 0.11 & 0.15 & 0.16 & 0.30 \\
\hline Sweden & -0.15 & 0.09 & 0.12 & 0.19 & -0.10 & 0.33 & 0.14 & 0.09 & 0.12 & 0.15 & 0.17 & 0.16 & 0.19 & 0.28 & 0.15 & 0.22 & 0.20 & 0.16 & 0.34 & 0.15 & 0.17 & -0.07 & 0.17 & 0.15 & 0.30 \\
\hline Spain & -0.08 & 0.21 & 0.17 & 0.16 & -0.04 & 0.11 & 0.19 & 0.20 & 0.08 & 0.17 & 0.01 & 0.11 & -0.01 & 0.08 & -0.02 & 0.66 & 0.29 & 0.11 & 0.18 & 0.05 & 0.14 & 0.03 & 0.14 & 0.12 & 0.08 \\
\hline Turkey & 0.19 & 0.16 & 0.29 & 0.07 & 0.13 & 0.04 & 0.20 & 0.32 & 0.01 & 0.04 & -0.11 & -0.05 & -0.01 & 0.18 & -0.16 & 0.01 & -0.04 & 0.22 & -0.01 & -0.04 & 0.18 & 0.01 & -0.07 & 0.03 & 0.05 \\
\hline Japan & 0.17 & 0.06 & -0.04 & -0.03 & -0.08 & 0.04 & 0.05 & 0.12 & 0.09 & 0.08 & 0.00 & 0.12 & 0.13 & 0.07 & 0.00 & 0.17 & -0.10 & -0.05 & 0.13 & -0.02 & 0.13 & -0.03 & 0.06 & 0.11 & 0.11 \\
\hline China & -0.14 & 0.00 & 0.19 & 0.10 & 0.05 & 0.12 & 0.14 & 0.00 & 0.06 & 0.20 & 0.04 & 0.18 & 0.05 & 0.10 & 0.07 & 0.07 & 0.14 & 0.04 & 0.13 & 0.04 & 0.15 & -0.06 & 0.07 & 0.11 & 0.13 \\
\hline Peru & -0.03 & -0.08 & 0.01 & -0.03 & 0.00 & -0.08 & 0.02 & 0.04 & 0.02 & 0.07 & 0.06 & -0.09 & 0.06 & 0.01 & 0.15 & 0.10 & -0.10 & 0.05 & 0.05 & -0.02 & 0.16 & 0.11 & 0.03 & 0.04 & -0.12 \\
\hline Argentina & 0.00 & 0.05 & 0.04 & 0.04 & -0.02 & 0.15 & 0.02 & 0.20 & 0.12 & 0.18 & 0.05 & 0.07 & 0.04 & 0.15 & 0.09 & 0.09 & 0.12 & 0.01 & 0.10 & 0.05 & 0.12 & -0.03 & 0.05 & 0.00 & 0.10 \\
\hline USA & -0.07 & -0.09 & 0.15 & 0.02 & -0.01 & 0.02 & 0.04 & 0.18 & -0.03 & -0.03 & -0.02 & 0.14 & 0.18 & 0.08 & -0.12 & 0.04 & 0.16 & -0.09 & -0.08 & -0.09 & 0.01 & 0.11 & -0.06 & 0.07 & -0.04 \\
\hline Canada & -0.11 & 0.07 & 0.20 & 0.23 & 0.18 & 0.15 & 0.06 & 0.15 & 0.02 & 0.17 & 0.03 & -0.05 & 0.29 & 0.12 & 0.08 & 0.09 & 0.08 & 0.08 & 0.20 & 0.21 & 0.15 & 0.10 & 0.12 & 0.25 & 0.31 \\
\hline France & 0.11 & 0.10 & 0.08 & -0.04 & -0.27 & 0.32 & 0.27 & 0.12 & 0.10 & 0.25 & 0.10 & 0.08 & 0.09 & 0.23 & 0.21 & 0.42 & 0.19 & 0.12 & 0.32 & 0.21 & 0.14 & 0.00 & 0.23 & 0.21 & 0.28 \\
\hline Germany & 0.12 & 0.15 & 0.11 & 0.09 & -0.14 & 0.25 & 0.17 & 0.01 & 0.22 & 0.20 & 0.09 & 0.07 & 0.19 & 0.22 & 0.13 & 0.31 & 0.26 & 0.20 & 0.36 & 0.08 & 0.26 & -0.07 & 0.17 & 0.24 & 0.23 \\
\hline Indonesia & 0.06 & 0.18 & 0.20 & 0.21 & 0.14 & 0.10 & 0.16 & 0.00 & 0.11 & 0.04 & 0.05 & 0.19 & 0.20 & 0.12 & 0.16 & 0.44 & 0.09 & 0.06 & 0.15 & 0.14 & 0.22 & 0.08 & 0.18 & 0.27 & 0.18 \\
\hline $\begin{array}{c}\text { New } \\
\text { Zealand }\end{array}$ & -0.22 & 0.04 & -0.01 & -0.07 & -0.15 & 0.29 & 0.22 & 0.23 & 0.03 & 0.14 & 0.15 & 0.15 & 0.24 & 0.14 & 0.16 & 0.16 & 0.06 & 0.02 & 0.22 & 0.15 & 0.22 & 0.10 & 0.23 & 0.13 & 0.09 \\
\hline Denmark & -0.04 & 0.11 & 0.02 & 0.03 & -0.28 & 0.34 & 0.15 & -0.11 & 0.21 & 0.08 & 0.29 & 0.06 & 0.11 & 0.27 & 0.15 & 0.08 & 0.21 & 0.23 & 0.27 & 0.03 & 0.04 & -0.12 & 0.21 & 0.11 & 0.48 \\
\hline Bangladesh & -0.07 & 0.01 & 0.00 & 0.05 & 0.10 & 0.02 & 0.11 & 0.10 & -0.22 & -0.01 & -0.10 & 0.00 & 0.08 & -0.01 & -0.06 & 0.06 & 0.11 & 0.10 & 0.04 & 0.12 & 0.13 & 0.27 & 0.08 & -0.07 & -0.16 \\
\hline Ireland & 0.01 & 0.01 & 0.08 & -0.24 & 0.04 & 0.05 & 0.07 & 0.42 & 0.10 & 0.14 & 0.04 & 0.03 & 0.15 & 0.06 & 0.18 & 0.17 & -0.01 & 0.12 & 0.08 & 0.06 & 0.18 & -0.05 & 0.02 & 0.11 & 0.13 \\
\hline Switzerland & -0.08 & 0.10 & 0.16 & 0.12 & -0.07 & 0.29 & 0.09 & -0.11 & 0.21 & 0.21 & 0.14 & 0.05 & 0.26 & 0.20 & 0.20 & 0.20 & 0.22 & 0.04 & 0.32 & 0.16 & 0.16 & 0.03 & 0.24 & 0.28 & 0.24 \\
\hline Australia & -0.09 & 0.07 & -0.01 & -0.02 & -0.13 & 0.22 & 0.14 & 0.26 & 0.21 & 0.15 & 0.20 & 0.01 & 0.18 & 0.13 & 0.19 & 0.15 & 0.17 & 0.05 & 0.18 & 0.06 & 0.10 & 0.00 & 0.20 & 0.17 & 0.35 \\
\hline Brazil & -0.06 & 0.06 & 0.16 & -0.03 & 0.29 & 0.12 & 0.22 & -0.07 & 0.11 & 0.28 & 0.08 & 0.21 & 0.03 & 0.11 & 0.19 & 0.12 & 0.11 & 0.22 & 0.08 & 0.15 & 0.25 & 0.03 & 0.18 & 0.12 & 0.11 \\
\hline UK & -0.02 & 0.10 & 0.16 & 0.05 & 0.09 & 0.27 & 0.07 & 0.21 & 0.20 & 0.15 & 0.16 & 0.14 & 0.17 & 0.32 & 0.23 & 0.12 & 0.15 & 0.08 & 0.40 & 0.05 & 0.05 & -0.06 & 0.12 & 0.21 & 0.27 \\
\hline Taiwan & -0.07 & -0.04 & -0.02 & 0.01 & -0.21 & 0.05 & 0.23 & -0.06 & 0.11 & 0.16 & -0.10 & 0.10 & -0.10 & 0.09 & 0.23 & -0.01 & -0.04 & -0.01 & 0.09 & 0.11 & 0.26 & 0.01 & -0.02 & 0.05 & 0.04 \\
\hline $\begin{array}{l}\text { Hong } \\
\text { Kong }\end{array}$ & -0.13 & 0.16 & -0.07 & 0.06 & -0.24 & 0.19 & 0.41 & 0.03 & 0.19 & 0.17 & 0.15 & 0.06 & 0.18 & 0.25 & 0.04 & 0.00 & 0.16 & 0.13 & 0.25 & 0.08 & 0.21 & -0.04 & 0.21 & 0.11 & 0.20 \\
\hline Average & -0.04 & 0.09 & 0.08 & 0.04 & -0.04 & 0.15 & 0.14 & 0.09 & 0.11 & 0.14 & 0.07 & 0.08 & 0.12 & 0.15 & 0.11 & 0.17 & 0.11 & 0.08 & 0.18 & 0.08 & 0.15 & 0.03 & 0.13 & 0.13 & 0.16 \\
\hline $\begin{array}{l}\text { \% Sig. } \\
\text { Corr. }\end{array}$ & $4 \%$ & $8 \%$ & $4 \%$ & $0 \%$ & $0 \%$ & $40 \%$ & $28 \%$ & $4 \%$ & $28 \%$ & $40 \%$ & $16 \%$ & $12 \%$ & $36 \%$ & $36 \%$ & $36 \%$ & $32 \%$ & $12 \%$ & $8 \%$ & $52 \%$ & $8 \%$ & $32 \%$ & $4 \%$ & $4 \%$ & $28 \%$ & $48 \%$ \\
\hline
\end{tabular}




\section{Regression Analysis}

\subsection{Empirical Model}

In light of the results from the correlation coefficients presented in Table 3, and following Karolyi et al. (2012), we utilized the seemingly unrelated regressions (SUR) approach to estimate the effect of oil factors on commonality in liquidity. This approach accounts for correlations in the time-effect residuals of commonality in liquidity across countries as opposed to estimating the effects from separate ordinary least squares (OLS) regressions and allows us to restrict certain coefficients across equations (countries). The estimated structural equation model is as follows:

$$
R_{\text {Amihud }}^{2}=\alpha_{g}+\beta_{g} \text { Oil Return }_{c, t}+\gamma_{g} \text { Oil Volatility }_{c, t}+\delta_{g}^{\prime} \text { Controls }_{c t}+\varepsilon_{c, t},
$$

where $E\left[\varepsilon_{c t}\right]=0 ; E\left[\varepsilon_{i i}{ }^{\prime} \varepsilon_{i j}\right]=0, E\left[\varepsilon_{i i}{ }^{\prime} \varepsilon_{i i}\right]=\sigma_{i}^{2}$, and $E\left[\varepsilon_{i i}{ }^{\prime} \varepsilon_{j i}\right]=\sigma_{i j}^{2}$. The subscript $\mathrm{c}$ represents the 50 country equations and $t$ represents the month; the dependent variable $R_{\text {Amihud }}^{2}$ is transformed in the form: $\ln \left[\frac{R_{\text {Amihud }}^{2}}{1-R_{\text {Amihud }}^{2}}\right]$. The coefficients $\alpha_{g}, \beta_{g}, \gamma_{g}$, and $\delta_{g}$ are restricted to be equal in all equations in the group $g$.

First, we estimated the model and restricted all coefficients to be the same in all countries in our sample. Since the effect of oil is hypothesized to play a more significant role in countries that are relatively more sensitive to the oil market, we allowed the coefficients to change across two groups: highly oil-sensitive and less oil-sensitive countries. In order to ensure that the differences between the high- and low-sensitivity countries were not driven by the inclusion of many major net exporters in the highly oil-sensitive group, we relaxed the coefficient restrictions between net exporters and net importers and allowed them to differ. In addition, this allowed us to investigate whether the effect of oil on commonality in liquidity is asymmetric across net oil exporters and net oil importers after controlling for oil sensitivity. To accomplish this, we defined three groups: less oil-sensitive countries, highly oil-sensitive net exporter countries, and highly oil-sensitive net importer countries. We then allowed the coefficients to be different for each group.

The latter test, however, might have suffered from an endogeneity problem. Although we controlled for oil sensitivity by restricting the countries of net exporters and net importers to be in or withdrawn from the highly oil-sensitive classification, any asymmetric effect of oil factors on commonality in liquidity could have been attributed to the fact that net exporters are, on average, more oil-sensitive than net importers. The five most oil-sensitive countries in our sample were the net exporter members of OPEC. To address this issue and re-examine the asymmetric effect of oil factors on commonality in liquidity in net exporters versus net importers, we further split the countries into four groups: less oil-sensitive countries, highly oil-sensitive OPEC net exporter countries, highly oil-sensitive non-OPEC net exporters and highly oil-sensitive net importer.

\subsection{Results}

With the aim of exploring the relationship between the oil market factors and commonality in liquidity, we specified a set of hypotheses (see Section 2.1). The first two hypotheses state that commonality in liquidity is expected to have a negative relationship with oil market returns and a positive relationship with oil market volatility. Table 4 presents the estimation results from the seemingly unrelated regressions, where we restricted the coefficients to be equal across all countries to impose homogeneity for all countries. ${ }^{13} \mathrm{In}$ Models 1, 3, 5, and 7, we show the results from including different sets of control variables other than the oil factors. Particularly, in Models 1, 3, and 5, respectively, we include market condition variables only, market condition and supply factors, market condition and demand factors, and market condition variables, supply factors, and demand factors. Conversely, in Models 2, 4, 6, and 8, we included oil factors in the equations. Consistent with Karolyi et al. (2012), we found that commonality in liquidity is associated with decreased market returns, time, capital market openness (proxied by the gross capital 
flow scaled by GDP), and US sentiment but increased market volatility, market turnover, credit constraints (proxied by the local short-term interest rate), and turnover commonality $\left(R_{\text {turnover }}^{2}\right)$. All these effects were statistically significant and had the expected signs.

The coefficients of oil factors, namely oil return and oil volatility, had the expected signs but were statistically insignificant. Intuitively, the results from Table 4 indicate that a zero effect of oil factors in explaining commonality in liquidity across countries cannot be rejected. To test the explanatory power of oil factors and whether they captured the variations in commonality in liquidity that are not captured by the control variables, we reported the adjusted $R^{2}$ from separate OLS regressions for each country and compared the means and medians of the model that does not include oil factors with the model that included them. The adjusted $R^{2}$ without oil factors was $16.31 \%$ and it increased to $16.63 \%$ when we included oil factors, indicating an increase of less than $2 \%$. In light of these results, we can conclude that oil market variables may not contribute to the commonality in equity in all countries. Therefore, we explored further to gain additional insights into this issue. Thus far, we have not allowed for any variation in coefficients in our base model regression. In the next part, we will relax the restriction placed on the coefficient to have better insights into the current research question. Although the impact of oil price having a weak impact on commonality in liquidity is consistent with recent studies such as Chiang and Hughen (2017), the impact of volatility on commonality in liquidity is expected to be strong according to the findings in Christoffersen and Pan (2018).

As stated in Hypothesis 3, we expect that the oil factors will explain commonality in liquidity in countries that are more integrated to the oil market. To test this hypothesis, we allowed the coefficients to vary across two groups, namely the highly oil-sensitive and less oil-sensitive groups. Table 5 reports the results from the seemingly unrelated regressions in which we restricted the coefficients to be equal within each group and to vary across groups. Models $1 \mathrm{~A}$ and $1 \mathrm{~B}$ include all control variables except for oil factors, whereas Models 2A and 2B include oil factors as well. Similarly, we reported the mean and median $R^{2}$ of separate regressions for each country and we reported the Wald test for the difference between the coefficients in the two groups. The coefficient of oil volatility was positive and statistically significant at the $1 \%$ statistical level for the highly oil-sensitive group. Conversely, the coefficient of oil volatility was negative and statistically insignificant for the less oil-sensitive group. This difference in the effect of oil volatility between the two groups was statistically significant. For oil returns, the coefficient was negative and only statistically significant for the highly oil-sensitive group in the one-sided test. However, the difference in the effect of oil returns on the highly oil-sensitive group versus the less oil-sensitive group was statistically insignificant. Overall, the results reported in Table 5 revealed the importance of accounting for the heterogeneity of countries based on oil sensitivity and supported Hypothesis 3 . Returns and volatility were significant for highbut not low-sensitivity countries. As hypothesized, the impact of the oil market was stronger in highly oil-sensitive countries than in less oil-sensitive countries. This differing impact was more pronounced for market volatility, as the Wald test was significant for volatility but not for oil returns. This finding supports the significant relationship between oil market volatility and macroeconomic variables reported in Chiang et al. (2015). 


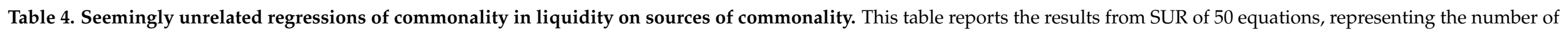

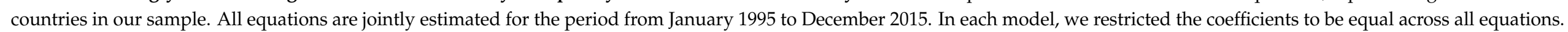

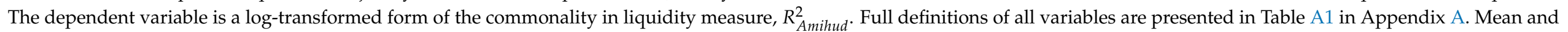
medians of adjusted $R^{2}$ reported in the last two rows are taken from separate optimum least squares regressions of all countries.

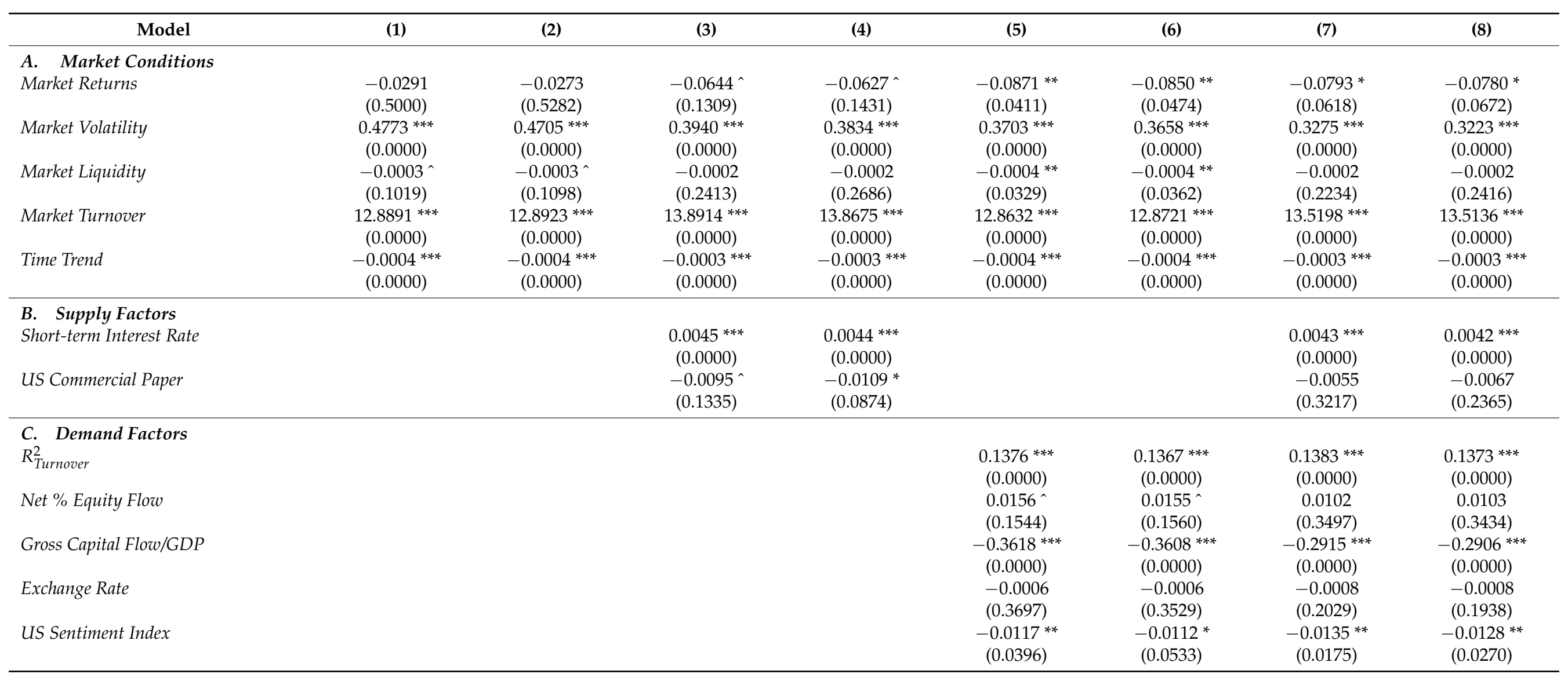


Table 4. Cont.

\begin{tabular}{|c|c|c|c|c|c|c|c|c|c|}
\hline \multicolumn{2}{|c|}{ Model } & (1) & (2) & (3) & (4) & (5) & (6) & (7) & (8) \\
\hline \multicolumn{10}{|c|}{ D. Oil Factors } \\
\hline \multicolumn{3}{|c|}{ Oil Returns } & $\begin{array}{l}-0.0432 \\
(0.3390)\end{array}$ & & $\begin{array}{c}-0.0576^{\wedge} \\
(0.1988)\end{array}$ & & $\begin{array}{l}-0.0396 \\
(0.3285)\end{array}$ & & $\begin{array}{l}-0.0403 \\
(0.3250)\end{array}$ \\
\hline \multicolumn{2}{|l|}{ Oil Volatility } & & $\begin{array}{c}1.1152 \\
(0.3379)\end{array}$ & & $\begin{array}{l}1.7765^{\wedge} \\
(0.1183)\end{array}$ & & $\begin{array}{c}0.8720 \\
(0.4008)\end{array}$ & & $\begin{array}{c}1.1969 \\
(0.2501)\end{array}$ \\
\hline \multicolumn{2}{|l|}{ Intercept } & $\begin{array}{c}-1.3153^{* * *} \\
(0.0000)\end{array}$ & $\begin{array}{c}-1.3206^{* * *} \\
(0.0000)\end{array}$ & $\begin{array}{c}-1.3533^{* * *} \\
(0.0000)\end{array}$ & $\begin{array}{c}-1.3626^{* * *} \\
(0.0000)\end{array}$ & $\begin{array}{c}-1.2995^{* * *} \\
(0.0000)\end{array}$ & $\begin{array}{c}-1.3045^{* * *} \\
(0.0000)\end{array}$ & $\begin{array}{c}-1.3354^{* * *} \\
(0.0000)\end{array}$ & $\begin{array}{c}-1.3422^{* * *} \\
(0.0000)\end{array}$ \\
\hline \multirow{2}{*}{$\begin{array}{l}\text { \# Obs. } \\
\text { Adjusted } R^{2}\end{array}$} & & 10,681 & 10,681 & 10,050 & 10,050 & 10,000 & 10,000 & 9902 & 9902 \\
\hline & $\begin{array}{l}\text { Mean } \\
\text { Median }\end{array}$ & $\begin{array}{c}10.98 \% \\
5.86 \%\end{array}$ & $\begin{array}{c}11.34 \% \\
6.53 \%\end{array}$ & $\begin{array}{c}11.23 \% \\
5.36 \%\end{array}$ & $\begin{array}{c}11.84 \% \\
6.86 \%\end{array}$ & $\begin{array}{l}15.32 \% \\
12.98 \%\end{array}$ & $\begin{array}{l}15.51 \% \\
13.28 \%\end{array}$ & $\begin{array}{l}16.31 \% \\
13.83 \%\end{array}$ & $\begin{array}{l}16.63 \% \\
14.15 \%\end{array}$ \\
\hline
\end{tabular}

$* * *, * *, *$, and ${ }^{\wedge}$ refer to the $1 \%, 5 \%, 10 \%$, and one-sided statistical levels, respectively.

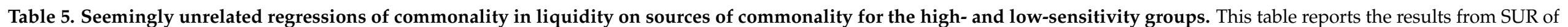

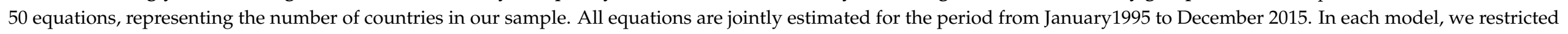

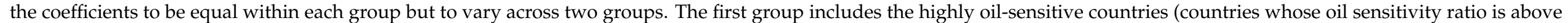

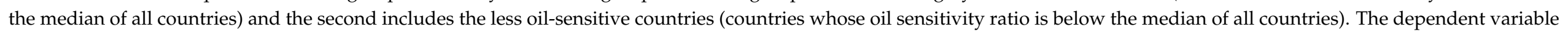

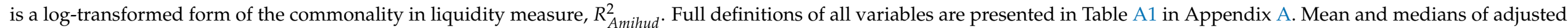

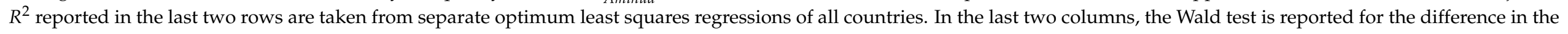
coefficients between groups.

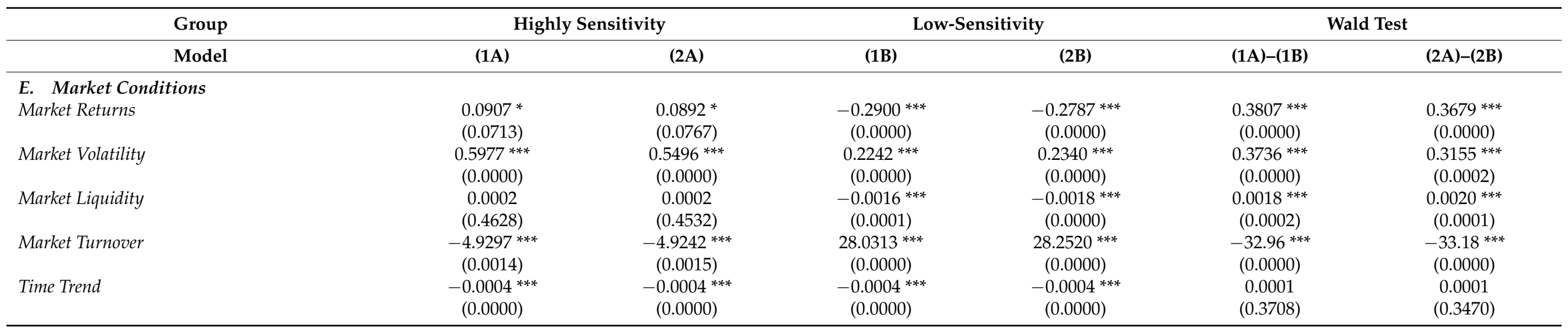


Table 5. Cont.

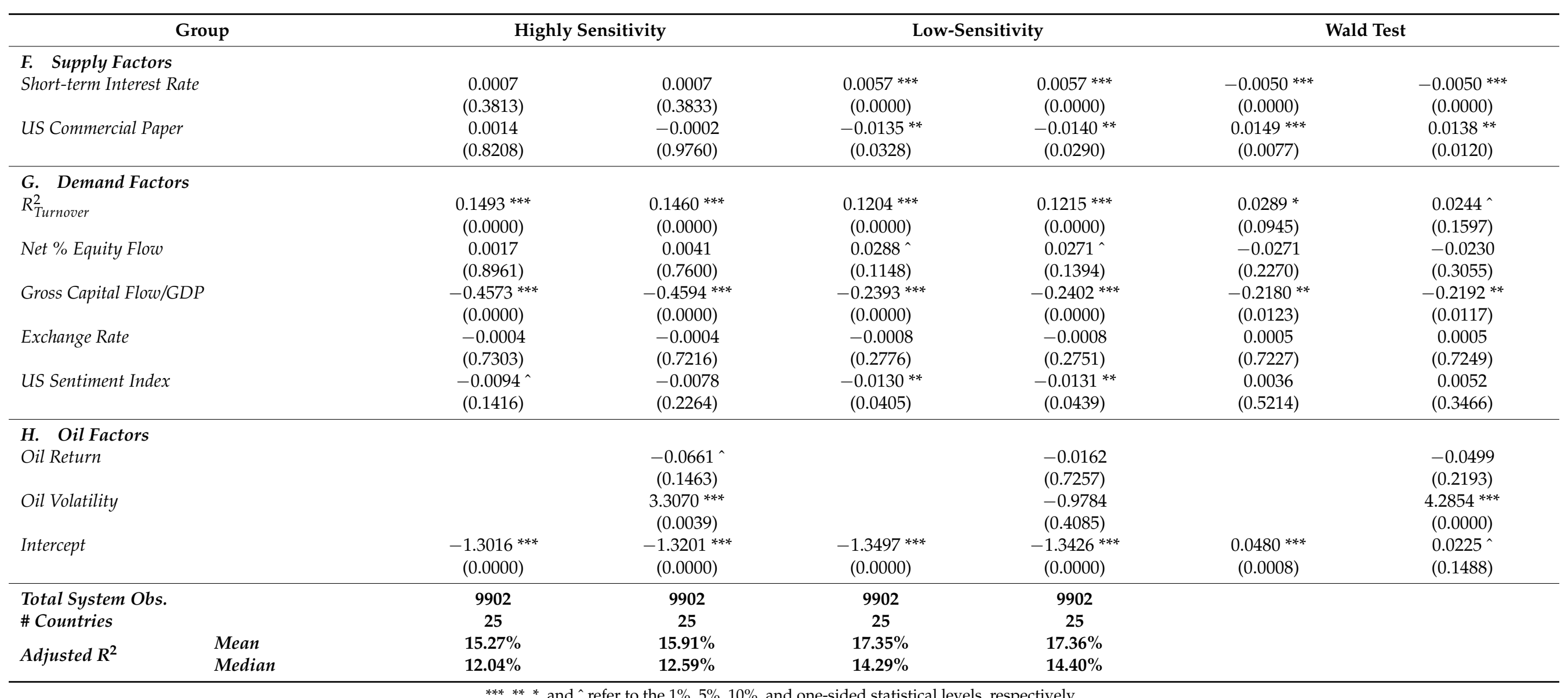


Thus far, we have seen that oil factors, specifically oil volatility, contribute to explaining commonality in liquidity only in countries that are more oil-sensitive. This evidence is supported by two other aspects. First, we see that for highly oil-sensitive countries, when we include oil factors in the separate OLS regressions, the means and medians of the adjusted $R^{2}$ increase by $4.2 \%$ and $4.6 \%$, respectively. Conversely, for less oil-sensitive countries, the improvements in adjusted $R^{2}$ are from close to zero to less than $1 \%$. Second, for each group, we compare the intercept of the models that do not include oil factors with the ones that do. Before controlling for oil factors, the intercepts of the high- and low-sensitivity groups are economically and statistically different from each other at the $1 \%$ statistical level. However, when we control for oil factors, this difference shrinks to half and becomes statistically insignificant. This indicates that oil factors capture the variations in the average commonality in liquidity across the two groups, which, in turn, emphasizes the importance of oil factors in explaining commonality in liquidity variations in the highly oil-sensitive group.

Next, we explore the nature of highly oil-sensitive countries regarding which oil market factors are more significant compared with less oil-sensitive ones, in that several are net exporters, but others are net importers. Commonality in liquidity may behave differently in mainly exporting and mainly importing countries, even if both are highly oil-sensitive countries. As per Hypothesis 4, the expectation is that the impact of oil market factors on liquidity will be stronger in net exporters than in net importers. Table 6 shows the results from the test of the asymmetric effect of oil factors on net oil exporters versus net oil importers. In Models 1A and 2A, we report the coefficients of the regressions that were restricted to be equal within the highly oil-sensitive net exporters (10 countries). In Models $1 \mathrm{~B}$ and $2 \mathrm{~B}$, we report the coefficients of the regressions that were restricted to be equal within the highly oil-sensitive net importers (15 countries). As expected, the effect of oil returns is economically and statistically stronger in the highly oil-sensitive net exporters. The coefficient of oil returns is -0.145 , which is statistically significant at the $10 \%$ level in the highly oil-sensitive net exporter group, but it is -0.056 , which is statistically insignificant, in the less oil-sensitive net importer group. However, according to the Wald test, this difference is statistically insignificant. Conversely, the coefficient of oil volatility for the highly oil-sensitive net exporter group (6.75) is more than double the coefficient for the less oil-sensitive net importer group (2.87). This difference is statistically significant at the $5 \%$ statistical level. The results suggest that the commonality in liquidity for net exporters is more influenced by oil factors than it is for net importers, after controlling for oil sensitivity. Overall, the results, which support Hypothesis 4, are presented in Table 5 where, although oil market returns are significant for both net exporters and net importers, oil market volatility is significant for net exporters only. 
Table 6. Seemingly unrelated regressions of commonality in liquidity on sources of commonality: net exporters and net importers. This table reports the results from SUR of 50 equations, representing the number of countries in our sample. All equations are jointly estimated for the period from January 1995 to December 2015. In each model, we restricted the coefficients to be equal within each group but to vary across three groups. The first group includes the highly oil-sensitive net exporters (countries whose oil sensitivity ratio is above the median of all countries and that are net exporters), the second includes highly oil-sensitive and net importers (countries whose oil sensitivity ratio is above the median of all countries and that are net importers), and the third includes less oil-sensitive countries (countries whose oil sensitivity ratio is below the median of all countries). The third group's results are suppressed since they are presented in Table 4 . The dependent variable is a log-transformed form of the commonality in liquidity measure, $R_{\text {Amihud }}^{2}$. Full definitions of all variables are presented in Table A1 in Appendix A. In the last two columns, the Wald test is reported for the difference in the coefficients between groups.

\begin{tabular}{|c|c|c|c|}
\hline \multirow{2}{*}{ Group } & High Oil Sens./Net Exporter & High Oil Sens./Net Importer & Wald Test \\
\hline & (A) & (B) & (A)-(B) \\
\hline \multicolumn{4}{|l|}{ I. Market Conditions } \\
\hline Market Returns & $\begin{array}{c}-0.1503^{\wedge} \\
(0.1535)\end{array}$ & $\begin{array}{l}0.1468^{* * *} \\
(0.0076)\end{array}$ & $\begin{array}{c}-0.2971^{* * *} \\
(0.0100)\end{array}$ \\
\hline Market Volatility & $\begin{array}{c}0.4248^{* * *} \\
(0.0022)\end{array}$ & $\begin{array}{c}0.4549 * * * \\
(0.0000)\end{array}$ & $\begin{array}{l}-0.0300 \\
(0.8506)\end{array}$ \\
\hline Market Liquidity & $\begin{array}{c}0.0003 \\
(0.2696)\end{array}$ & $\begin{array}{l}-0.0002 \\
(0.5990)\end{array}$ & $\begin{array}{c}0.0005 \\
(0.2863)\end{array}$ \\
\hline Market Turnover & $\begin{array}{c}42.2573^{* * *} \\
(0.0000)\end{array}$ & $\begin{array}{c}-7.5691^{* * *} \\
(0.0000)\end{array}$ & $\begin{array}{c}49.8263^{* * *} \\
(0.0000)\end{array}$ \\
\hline Time Trend & $\begin{array}{c}-0.0002 \\
(0.0545)\end{array}$ & $\begin{array}{c}-0.0004^{* * *} \\
(0.0000)\end{array}$ & $\begin{array}{l}0.0002^{\wedge} \\
(0.1099)\end{array}$ \\
\hline \multicolumn{4}{|l|}{ J. Supply Factors } \\
\hline Short-term Interest Rate & $\begin{array}{l}-0.0007 \\
(0.6087)\end{array}$ & $\begin{array}{c}0.0026^{* * *} \\
(0.0026)\end{array}$ & $\begin{array}{l}-0.0033^{* *} \\
(0.0335)\end{array}$ \\
\hline US Commercial Paper & $\begin{array}{c}-0.0183 \text { * } \\
(0.0799)\end{array}$ & $\begin{array}{c}0.0010 \\
(0.8729) \\
\end{array}$ & $\begin{array}{c}-0.0193 * \\
(0.0576)\end{array}$ \\
\hline \multicolumn{4}{|l|}{ K. Demand Factors } \\
\hline$R_{\text {Turnover }}^{2}$ & $\begin{array}{c}0.2070^{* * *} \\
(0.0000)\end{array}$ & $\begin{array}{c}0.1383^{* * *} \\
(0.0000)\end{array}$ & $\begin{array}{l}0.0687^{* *} \\
(0.0399)\end{array}$ \\
\hline Net \% Equity Flow & $\begin{array}{c}0.0472 \\
(0.2178)\end{array}$ & $\begin{array}{c}0.0017 \\
(0.9068)\end{array}$ & $\begin{array}{c}0.0455 \\
(0.2653)\end{array}$ \\
\hline Gross Capital Flow/GDP & $\begin{array}{c}-6.6289 * * * \\
(0.0000)\end{array}$ & $\begin{array}{c}0.0609 \\
(0.4960)\end{array}$ & $\begin{array}{l}-6.6898^{* * * *} \\
(0.0000)\end{array}$ \\
\hline Exchange Rate & $\begin{array}{c}-0.0038^{\wedge} \\
(0.1233)\end{array}$ & $\begin{array}{c}0.0004 \\
(0.7547)\end{array}$ & $\begin{array}{c}-0.0041 \\
(0.1217)\end{array}$ \\
\hline US Sentiment Index & $\begin{array}{c}0.0007 \\
(0.9504) \\
\end{array}$ & $\begin{array}{c}-0.0114 \text { * } \\
(0.0830)\end{array}$ & $\begin{array}{c}0.0121 \\
(0.2748) \\
\end{array}$ \\
\hline \multicolumn{4}{|l|}{ L. Oil Factors } \\
\hline Oil Returns & $\begin{array}{c}-0.1452 * \\
(0.0632)\end{array}$ & $\begin{array}{l}-0.0560 \\
(0.2294)\end{array}$ & $\begin{array}{l}-0.0892 \\
(0.2429)\end{array}$ \\
\hline Oil Volatility & $\begin{array}{c}6.7453^{* * *} \\
(0.0004)\end{array}$ & $\begin{array}{l}2.8678^{* *} \\
(0.0154)\end{array}$ & $\begin{array}{l}3.8776^{* *} \\
(0.0409)\end{array}$ \\
\hline Intercept & $\begin{array}{c}-1.3128^{* * *} \\
(0.0000)\end{array}$ & $\begin{array}{c}-1.3336^{* * *} \\
(0.0000)\end{array}$ & $\begin{array}{c}0.0208 \\
(0.5059) \\
\end{array}$ \\
\hline $\begin{array}{l}\text { Total System Obs. } \\
\text { \# Countries }\end{array}$ & $\begin{array}{c}9902 \\
10\end{array}$ & $\begin{array}{c}9902 \\
15\end{array}$ & \\
\hline
\end{tabular}

$* * * * *, *$, and ^ refer to the $1 \%, 5 \%, 10 \%$, and one-sided statistical levels, respectively.

Nevertheless, as we pointed out in the previous section, the latter test may suffer from an endogeneity problem. This endogeneity rises from considering a country to be highly oil-sensitive if its oil sensitivity ratio is higher than the median and ignoring the possibility that countries in the high-sensitivity group may not be equally sensitive to the oil market. The five most oil-sensitive countries in our sample are the net exporter OPEC members. 
To address this issue, we further split the countries into four groups: less oil-sensitive, highly oil-sensitive OPEC members, highly oil-sensitive non-OPEC net exporters, and highly oil-sensitive net importers. Table 7 reports the results from the seemingly unrelated regressions, in which we restrict the coefficients to be the same within each group and to vary across these groups. The effect of oil returns is more economically and statistically significant for the highly oil-sensitive OPEC members, with a coefficient of -0.3517 , compared with the other groups, in which this effect shows no statistical significance. The difference of this effect is statistically significant compared with non-OPEC net exporters or net importers. This suggests that the commonality in liquidity in OPEC members, as major oil exporters, is affected not only by oil volatility but also strongly influenced by the expected oil price movements. For oil volatility, both net exporter groups show a higher impact on commonality in liquidity compared with net importers. The coefficient of oil volatility for non-OPEC net exporters is 7.33 compared with 2.76 for net importers, which are both statistically significant. This difference is statistically significant according to the Wald test. These results confirm our initial findings of the asymmetric effect of oil factors on commonality liquidity in net exporters and net importers and verify that our findings are not influenced by the inclusion of OPEC members in the net exporter group.

\subsection{Robustness Check}

Because of the lack of a theoretical basis for the link between oil factors and stock liquidity, one may argue that the empirical findings in this paper may possibly be driven by the potential high correlations between oil factors and market factors. It has been shown by many recent studies, including this study, that market factors play a statistically and economically significant role in commonality in liquidity in equity markets. Therefore, one may suspect that the conclusions about the role of oil factors on commonality in liquidity are a result of a multicollinearity issue. To address this issue, we use oil market variables that are orthogonal to market factors in the regressions. Specifically, oil factors are orthogonalized by taking the residuals of the regressions of oil factors on market factors.

In Table 8, we report the results from all our analyses with orthogonalized oil factors. Panels A, B, C, and D validate the results presented in Tables 4-7, respectively. Generally, Table 8 indicates qualitatively similar results and confirms our previous empirical findings. Panel A re-estimates Models 2, 4, 6, and 8 from Table 4 but with the oil market variables orthogonalized to market-level variables. Oil returns are negative and significant, whereas oil volatility is mostly insignificant as reported in Table 4. In Table 5, Model 2A includes data from highly oil-sensitive countries, and Model 2B is based on less oil-sensitive countries. Panel B re-estimates these two models and confirms that the coefficients on oil returns and oil volatility for highly oil-sensitive countries remain significant with the expected signs after orthogonalized oil market variables are used. Similarly, Panels C and D replicate Tables 6 and 7 but with orthogonalized oil market variables and reaffirm our earlier findings. 


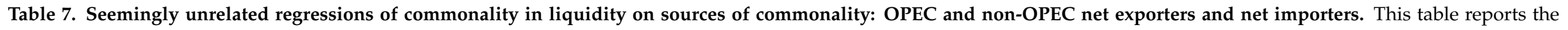

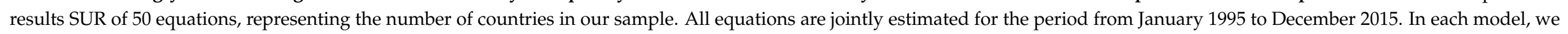

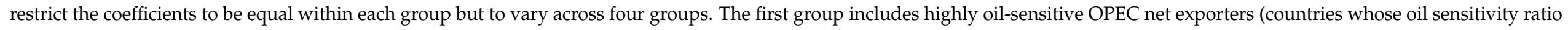

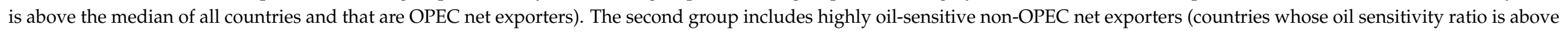

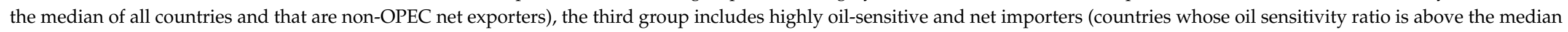

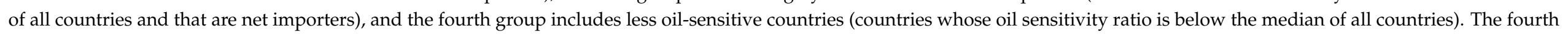

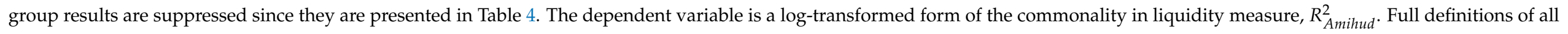
variables are presented in Table A1 in Appendix A. The Wald test is reported for the difference in the coefficients between groups.

\begin{tabular}{|c|c|c|c|c|c|c|}
\hline Group & $\begin{array}{l}\text { High Oil Sens. } \\
\text { OPEC }\end{array}$ & $\begin{array}{c}\text { High Oil Sens. } \\
\text { Net Exp. (Non-OPEC) }\end{array}$ & $\begin{array}{l}\text { High Oil Sens. } \\
\text { Net Importer }\end{array}$ & & Wald Tests & \\
\hline Model & (1) & (2) & (3) & (1)-(2) & (1)-(3) & (2)-(3) \\
\hline \multicolumn{7}{|l|}{ A. Market Conditions } \\
\hline Market Returns & $\begin{array}{l}-0.6325^{* * *} \\
(0.0001)\end{array}$ & $\begin{array}{l}0.3400 * * \\
(0.0166)\end{array}$ & $\begin{array}{l}0.1535^{* * *} \\
(0.0053)\end{array}$ & $\begin{array}{c}-0.9724^{* * *} \\
(0.0000)\end{array}$ & $\begin{array}{l}-0.7859^{* * *} \\
(0.0000)\end{array}$ & $\begin{array}{c}0.1865 \\
(0.2054)\end{array}$ \\
\hline Market Volatility & $\begin{array}{l}-0.0001 \\
(0.9995)\end{array}$ & $\begin{array}{l}0.7636^{* * *} \\
(0.0000)\end{array}$ & $\begin{array}{c}0.4588^{* * * *} \\
(0.0000)\end{array}$ & $\begin{array}{c}-0.7638^{* * *} \\
(0.0068)\end{array}$ & $\begin{array}{c}-0.4590 * \\
(0.0525)\end{array}$ & $\begin{array}{l}0.3048^{\wedge} \\
(0.1089)\end{array}$ \\
\hline Market Liquidity & $\begin{array}{c}0.0001 \\
(0.6785)\end{array}$ & $\begin{array}{l}-0.0058 \\
(0.2075)\end{array}$ & $\begin{array}{l}-0.0002 \\
(0.5961)\end{array}$ & $\begin{array}{l}0.0059^{\wedge} \\
(0.1991)\end{array}$ & $\begin{array}{c}0.0003 \\
(0.5047)\end{array}$ & $\begin{array}{l}-0.0056 \\
(0.2254)\end{array}$ \\
\hline Market Turnover & $\begin{array}{c}73.8709^{* * *} \\
(0.0000)\end{array}$ & $\begin{array}{c}7.0972 \\
(0.4151)\end{array}$ & $\begin{array}{l}-7.7031^{* * *} \\
(0.0000)\end{array}$ & $\begin{array}{c}66.7737^{* * *} \\
(0.0000)\end{array}$ & $\begin{array}{l}81.5740^{* * *} \\
(0.0000)\end{array}$ & $\begin{array}{l}14.8003^{*} \\
(0.0980)\end{array}$ \\
\hline Time Trend & $\begin{array}{c}-0.0004^{\wedge} \\
(0.1734)\end{array}$ & $\begin{array}{c}-0.0004^{* *} \\
(0.0220)\end{array}$ & $\begin{array}{c}-0.0005^{* * *} \\
(0.0000)\end{array}$ & $\begin{array}{c}0.0000 \\
(0.8886) \\
\end{array}$ & $\begin{array}{c}0.0000 \\
(0.8831) \\
\end{array}$ & $\begin{array}{c}0.0001 \\
(0.5495)\end{array}$ \\
\hline \multicolumn{7}{|l|}{ B. Supply Factors } \\
\hline Short-term Interest Rate & $\begin{array}{l}0.0036^{\wedge} \\
(0.1524)\end{array}$ & $\begin{array}{l}-0.0013 \\
(0.4820)\end{array}$ & $\begin{array}{c}0.0025^{* * *} \\
(0.0037)\end{array}$ & $\begin{array}{l}0.0049^{\wedge} \\
(0.1192)\end{array}$ & $\begin{array}{c}0.0011 \\
(0.6864)\end{array}$ & $\begin{array}{l}-0.0038 * \\
(0.0513)\end{array}$ \\
\hline US Commercial Paper & $\begin{array}{l}-0.0169 \\
(0.3295)\end{array}$ & $\begin{array}{l}-0.0182^{\wedge} \\
(0.1477)\end{array}$ & $\begin{array}{c}0.0010 \\
(0.8743)\end{array}$ & $\begin{array}{c}0.0013 \\
(0.9500)\end{array}$ & $\begin{array}{l}-0.0180 \\
(0.3196)\end{array}$ & $\begin{array}{c}-0.0193 * \\
(0.0956)\end{array}$ \\
\hline \multicolumn{7}{|l|}{ C. Demand Factors } \\
\hline$R_{\text {Turnover }}^{2}$ & $\begin{array}{l}0.3335^{* * *} \\
(0.0000)\end{array}$ & $\begin{array}{l}0.1099 * * * \\
(0.0047)\end{array}$ & $\begin{array}{l}0.1388^{* * *} \\
(0.0000)\end{array}$ & $\begin{array}{c}0.2235^{* * *} \\
(0.0002)\end{array}$ & $\begin{array}{c}0.1946^{* * *} \\
(0.0001)\end{array}$ & $\begin{array}{l}-0.0289 \\
(0.4801)\end{array}$ \\
\hline Net \% Equity Flow & & $\begin{array}{c}0.0444 \\
(0.2369)\end{array}$ & $\begin{array}{c}0.0010 \\
(0.9452)\end{array}$ & & & $\begin{array}{c}0.0434 \\
(0.2791)\end{array}$ \\
\hline Gross Capital Flow/GDP & & $\begin{array}{l}-3.1078^{* * *} \\
(0.0032)\end{array}$ & $\begin{array}{c}0.0448 \\
(0.6179)\end{array}$ & & & $\begin{array}{l}-3.1526^{* * *} \\
(0.0029)\end{array}$ \\
\hline
\end{tabular}


Table 7. Cont

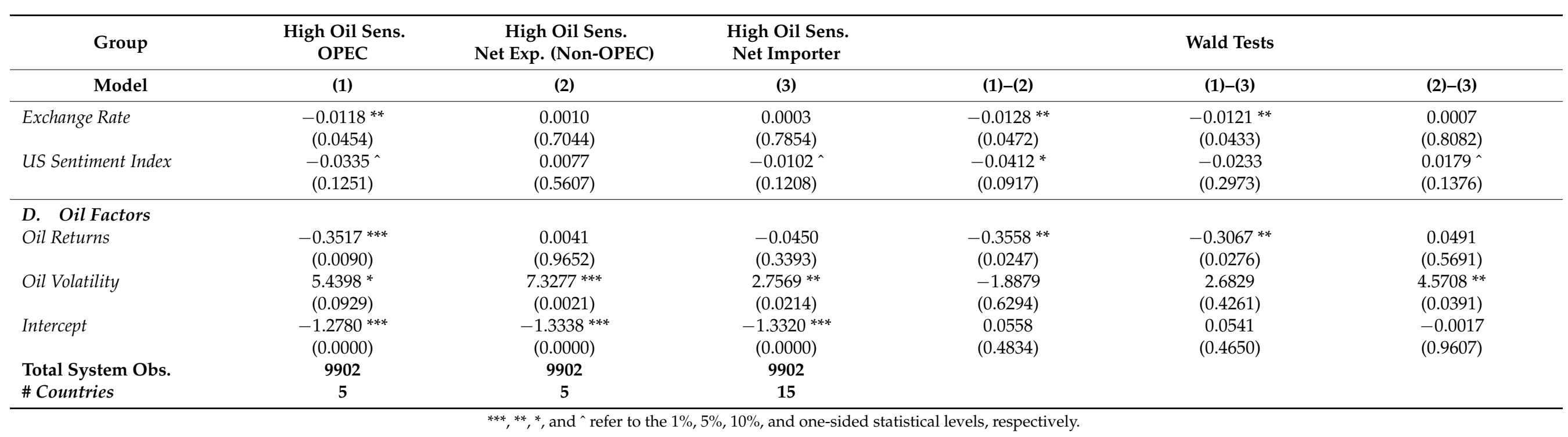

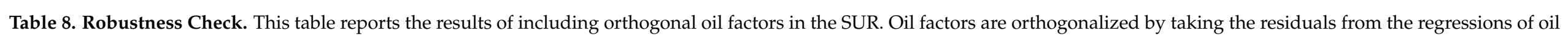

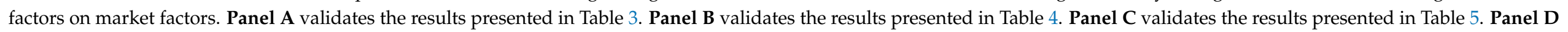
validates the results presented in Table 6.

\begin{tabular}{|c|c|c|c|c|}
\hline Panel A & & & & \\
\hline Group & All Countries & All Countries & All Countries & All Countries \\
\hline Model & (1) & (2) & (3) & (4) \\
\hline \multirow[t]{2}{*}{ Oil Volatility } & -0.6209 & 0.3918 & -0.1385 & 0.2148 \\
\hline & $(0.5843)$ & $(0.7222)$ & $(0.8920)$ & $(0.8327)$ \\
\hline Market Conditions & Yes & Yes & Yes & Yes \\
\hline Demand Factors & No & No & Yes & Yes \\
\hline
\end{tabular}


Table 8. Cont.

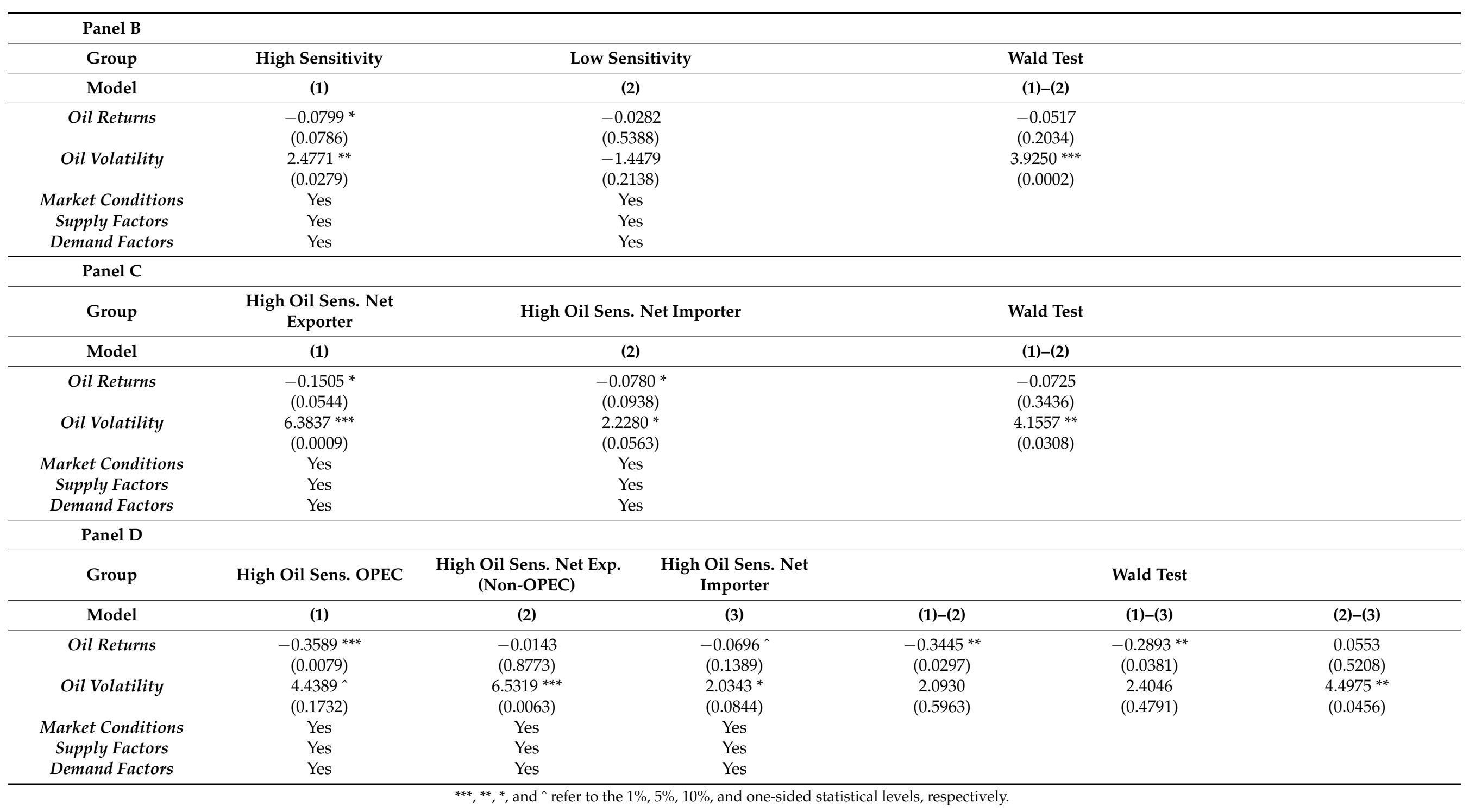




\section{Conclusions}

Previous studies have documented the existence of commonality in liquidity in international equity markets. More recently, extensive research has shown what may explain why equity market liquidity co-moves. This paper explores the impact of oil market returns and volatility on commonality in liquidity, especially in economies that are sensitive to oil market movements. Our sample includes a large number of markets from both developed and emerging economies. We use data from 36,930 firms from 50 countries. Within the explorative nature of this paper, we develop four hypotheses that guided our expectations regarding the behavior of commonality in liquidity across the full sample and within smaller samples. We define oil sensitivity as the absolute value of the difference between exports and imports scaled by the country's GDP. Our results show that the transmitting channels of oil factors, namely oil returns and volatility, explain variations in commonality in liquidity for countries that are somehow more oil-sensitive. Specifically, we show that the effects of oil volatility on commonality in liquidity are more substantial than the effects of oil returns when we restrict the coefficients of its effect to be equal for all countries that are considered to be highly oil-sensitive. In addition, we show that the effects of oil volatility are more pronounced in net oil exporters as opposed to net oil importers, after controlling for oil sensitivity.

The asymmetric effect of oil factors between net oil exporters and net oil importers is re-examined by allowing the coefficients to vary across the major exporters: OPEC members and non-OPEC net exporter members. The findings suggest that oil returns influence commonality in liquidity in OPEC members only, whereas oil volatility influences commonality in liquidity in both net oil exporter groups (i.e., OPEC and non-OPEC), as well as net oil importers. Lastly, we confirm the results that suggest a more pronounced effect of oil volatility on net oil exporters as opposed to net oil importers. Our results are robust to controlling for the possible sources of commonality in liquidity suggested in the literature.

The implications of the findings can be summarized as follows. The establishment of a statistically significant association between oil market and commonality in liquidity in equity markets can help anticipate and mitigate the negative impact of a contagious shock in liquidity in the equity markets, especially in economies that are highly integrated with the oil market. For investors, our findings also have vital implications, as it suggests the causal effect of oil factors on the price of liquidity risk, which increases the level of commonality in liquidity. For future research, we recommend studying the effects of oil shocks on commonality in liquidity by separating the sources of shocks and their directions. Kilian (2009) studied the dynamic effect of oil shocks on a set of economic factors and found that the effect of oil shocks is asymmetric in terms of whether they are driven by demand or supply sources. Possible research questions can be (1) whether the effects of different sources of oil shocks on commonality in liquidity are asymmetric, and (2) whether the effects of positive shocks and negative shocks on commonality in liquidity differ. Answers to similar questions are important for anticipating and mitigating or limiting the risk of contagious sudden decreasing in the equity markets, accelerated by high levels of commonality in liquidity.

Author Contributions: All authors have worked together on the entire manuscript and have agreed on this version for publication. All authors have read and agreed to the published version of the manuscript.

Funding: This research was funded by the Deanship of Scientific Research at the King Saud University.

Acknowledgments: We thank the participants at 2017 FMA annual meeting in Boston, especially Andrew Koch for his helpful comments. We would like to thank the Deanship of Scientific Research at the King Saud University represented by the research center at CBA for supporting this research financially. Comments and feedbacks of three anonymous reviewers on the manuscript are also thankfully acknowledged. 
Conflicts of Interest: The authors declare no conflict of interest.

\section{Appendix A}

Table A1. Descriptions of the variables. This table describes the variables used in the regression analysis in Section 3.

\begin{tabular}{|c|c|}
\hline Variable & Description \\
\hline Market returns & $\begin{array}{l}\text { The value-weighted average of the returns of all individual stocks in each country in a given month. } \\
\text { Data were obtained from Global Compustat. }\end{array}$ \\
\hline Market volatility & $\begin{array}{l}\text { The monthly standard deviation of the value-weighted market return multiplied by the square root } \\
\text { of } 22 \text { (the number of business days in a month). Data were obtained from Global Compustat. }\end{array}$ \\
\hline Market liquidity & $\begin{array}{l}\text { The value-weighted average of the monthly Amihud measure, computed as the average over the } \\
\text { month of the daily absolute stock returns divided by local currency trading volumes (multiplied by } \\
-100,000 \text { ) of all individual stocks in each country in a given month. Data are obtained from Global } \\
\text { Compustat. }\end{array}$ \\
\hline Market turnover & $\begin{array}{l}\text { The value-weighted average of the turnover, defined as the average daily trading volume divided by } \\
\text { the number of shares outstanding at the beginning of the year of all individual stocks in each country } \\
\text { in a given month. Data were obtained from Global Compustat. }\end{array}$ \\
\hline Short-term interest rate & $\begin{array}{l}\text { For each country, the local short-term interest rate is defined as the three-month treasury bills. If not } \\
\text { available, we use the money market rate, deposit rate, or the lending rate. Data were obtained from } \\
\text { the international financial statistics of IMF. }\end{array}$ \\
\hline US commercial spread & $\begin{array}{l}\text { The difference between the percentage of 90-day AA nonfinancial commercial paper interest rate and } \\
\text { the 3-month T-bill rate. Data were obtained from the Federal Reserve. }\end{array}$ \\
\hline$R_{\text {Turnover }}^{2}$ & $\begin{array}{l}\text { Computation is similar to the commonality in liquidity measure } R_{A m i h u d}^{2} \text {, which is described in detail } \\
\text { in Section 2.2. It is orthogonalized to the supply side factors by computing the residuals from a } \\
\text { regression of it on supply factors, namely local short-term interest rate and US commercial paper for } \\
\text { each country. Data were obtained from Global Compustat. }\end{array}$ \\
\hline Net $\%$ equity flow & $\begin{array}{l}\text { For each country, this is the difference of the item: "Gross sales of foreign stock by foreigners to US } \\
\text { residents" and the item "Gross purchases of foreign stocks by foreigners from US residents" scaled by } \\
\text { the sum of the two items. Data were obtained from Treasury International Capital (TIC). }\end{array}$ \\
\hline Gross capital flow /GDP & $\begin{array}{l}\text { For each country, this is the sum of the item: "Gross sales of long-term domestic and foreign } \\
\text { securities by foreigners to US residents and the item: "Gross purchases of long-term domestic and } \\
\text { foreign securities by foreigners from US residents" scaled by GDP. Data were obtained from Treasury } \\
\text { International Capital (TIC). }\end{array}$ \\
\hline Exchange rate & $\begin{array}{l}\text { For each country, this is the change in local currencies relative to special drawing rights (SDR). Data } \\
\text { were obtained from the international financial statistics of IMF. }\end{array}$ \\
\hline US Sentiment index & Constructed by Baker and Wurgler (2006) and obtained from Wurgler's website \\
\hline Oil returns & $\begin{array}{l}\text { Log of the difference of the oil futures price a } t \text { and } t-1 \text {. Data were obtained from the US Energy } \\
\text { information administration. }\end{array}$ \\
\hline Oil volatility & $\begin{array}{l}\text { The conditional variance of the GARCH process of oil returns. Details on the calculations can be } \\
\text { found in Section 2.3. Data were obtained from the US Energy Information Administration }\end{array}$ \\
\hline
\end{tabular}

\section{Notes}

1 Refer to Chordia et al. (2001), Amihud (2002), Pastor and Stambaugh (2003), Kamara et al. (2008), Hameed et al. (2010), Karolyi et al. (2012), Dang et al. (2015a, 2015b), Koch et al. (2016) and Moshirian et al. (2017), among others.

2 Algorithm trading's impact on liquidity is related more to the demand side than to the supply side.

3 For example, refer to Jones and Kaul (1996), Basher and Sadorsky (2006), Park and Ratti (2008), Elyasiani et al. (2011), Basher et al. (2012), and Degiannakis et al. (2013).

4 Brunnermeier and Pedersen (2009) presented a theoretical model in which lending agents such as financial intermediaries provide liquidity to equity markets but face funding constraints, as they have capital restrictions under uncertainty.

5 For a robustness check, we repeated our analysis with the spot prices of Western Texas Intermediate (WTI) crude oil and found that the results are qualitatively the same; these are not reported in the later sections. 
6 This approach is used to avoid the potential econometric problem of nonstationarity, which might be present if the liquidity measure is used as the dependent variable. Karolyi et al. (2012) also used this approach.

7 We require a minimum of 15 daily observations to estimate the $R^{2}$ of a stock in a given month.

8 This transformation is also used by Karolyi et al. (2012).

9 Coughenour and Saad (2004) also showed that stocks in the NYSE are handled by the same specialist with experience in co-movement in their liquidity.

10 The dataset was obtained from Wurgler's website.

11 Our data selection criteria are similar to those used by Karolyi et al. (2012).

12 Karolyi et al. (2012) used a sample obtained from Datastream that covered 40 countries from January 1995 to December 2012 , whereas, we used Global Compustat for 50 countries from January 1995 to December 2015.

13 Karolyi et al. (2012) also imposed this restriction in their paper.

\section{References}

Acharya, V., and L. Pedersen. 2005. Asset pricing with liquidity risk. Journal of Financial Economics 77: 375-410. [CrossRef]

Amihud, Y. 2002. Illiquidity and stock returns: Cross-section and time-series effects. Journal of Financial Markets 5: 31-56. [CrossRef]

Arezki, Rabah, and Olivier Blanchard. 2014. Seven Questions about the Recent Oil Price Slump. Washington: IMF Direct-The IMF Blog.

Atkins, A. B., and E. A. Dyl. 1997. Transactions costs and holding periods for common stocks. The Journal of Finance 52: 309-25. [CrossRef]

Baker, M., and J. Wurgler. 2006. Investor sentiment and the cross-section of stock returns. The Journal of Finance 61: 1645-80. [CrossRef]

Basher, S. A., and P. Sadorsky. 2006. Oil price risk and emerging stock markets. Global Finance Journal 17: 224-51. [CrossRef]

Basher, S. A., A. A. Haug, and P. Sadorsky. 2012. Oil prices, exchange rates and emerging stock markets. Energy Economics 34: 227-40. [CrossRef]

Basher, S. A., A. A. Haug, and P. Sadorsky. 2018. The impact of oil-market shocks on stock returns in major oil-exporting countries. Journal of International Money and Finance 86: 264-80. [CrossRef]

Brockman, P., D. Y. Chung, and C. Pérignon. 2009. Commonality in liquidity: A global perspective. Journal of Financial and Quantitative Analysis 44: 851-82. [CrossRef]

Brunnermeier, M. K., and L. H. Pedersen. 2009. Market liquidity and funding liquidity. Review of Financial Studies 22: 2201-38. [CrossRef]

Chen, N., R. Roll, and S. A. Ross. 1986. Economic forces and the stock market. Journal of Business 59: 383-403. [CrossRef]

Chiang, I. H. E., and W. K. Hughen. 2017. Do oil futures prices predict stock returns? Journal of Banking E Finance 79: $129-41$.

Chiang, I. H. E., W. K. Hughen, and J. S. Sagi. 2015. Estimating oil risk factors using information from equity and derivatives markets. The Journal of Finance 70: 769-804. [CrossRef]

Chordia, T., R. Roll, and A. Subrahmanyam. 2000. Commonality in liquidity. Journal of Financial Economics 56: 3-28. [CrossRef]

Chordia, T., A. Subrahmanyam, and V. R. Anshuman. 2001. Trading activity and expected stock returns. Journal of Financial Economics 59: 3-32. [CrossRef]

Christoffersen, P., and X. N. Pan. 2018. Oil volatility risk and expected stock returns. Journal of Banking E Finance 95: 5-26.

Coughenour, J. F., and M. M. Saad. 2004. Common market makers and commonality in liquidity. Journal of Financial Economics 73: 37-69. [CrossRef]

Dahl, R. E., A. Oglend, and M. Yahya. 2020. Dynamics of volatility spillover in commodity markets: Linking crude oil to agriculture. Journal of Commodity Markets 20: 100111. [CrossRef]

Dang, T. L., F. Moshirian, C. K. G. Wee, and B. Zhang. 2015a. Cross-listings and liquidity commonality around the world. Journal of Financial Markets 22: 1-26. [CrossRef]

Dang, T. L., F. Moshirian, and B. Zhang. 2015b. Commonality in news around the world. Journal of Financial Economics 116: 82-110. [CrossRef]

Degiannakis, S., G. Filis, and C. Floros. 2013. Oil and stock returns: Evidence from European industrial sector indices in a time-varying environment. Journal of International Financial Markets, Institutions and Money 26: 175-91. [CrossRef]

Deng, B., Z. Li, and Y. Li. 2018. Foreign institutional ownership and liquidity commonality around the world. Journal of Corporate Finance 51: 20-49. [CrossRef]

Driesprong, G., B. Jacobsen, and B. Maat. 2008. Striking oil: Another puzzle? Journal of Financial Economics 89: 307-27. [CrossRef]

Elyasiani, E., I. Mansur, and B. Odusami. 2011. Oil price shocks and industry stock returns. Energy Economics 33: 966-74. [CrossRef]

Gorton, G. B., and G. G. Pennacchi. 1993. Security baskets and index-linked securities. Journal of Business 66: 1-27. [CrossRef]

Hameed, A., W. Kang, and S. Viswanathan. 2010. Stock market declines and liquidity document the co-movements of market liquidity in equity markets. Journal of Finance 65: 257-93. [CrossRef]

Hamilton, J. D. 1983. Oil and the macroeconomy since World War II. Journal of Political Economy 91: 228-48. [CrossRef]

Hamilton, J. D. 2003. What is an oil shock? Journal of Econometrics 113: 363-98. [CrossRef]

Hasbrouck, J., and D. J. Seppi. 2001. Common factors in prices, order flows, and liquidity. Journal of Financial Economics 59: 383-411. [CrossRef] 
Hoesli, M., A. Kadilli, and K. Reka. 2017. Commonality in liquidity and real estate securities. The Journal of Real Estate Finance and Economics 55: 65-105. [CrossRef]

Huang, R. D., R. W. Masulis, and H. R. Stoll. 1996. Energy shocks and financial markets. Journal of Futures Market 16: 1-27. [CrossRef]

Isshaq, Z., and R. Faff. 2016. Does the uncertainty of firm-level fundamentals help explain cross-sectional differences in liquidity commonality? Journal of Banking \& Finance 68: 153-61.

Jones, C. M., and G. Kaul. 1996. Oil and the stock markets. Journal of Finance 51: 463-91. [CrossRef]

Kamara, A., X. Lou, and R. Sadka. 2008. The divergence of liquidity commonality in the cross-section of stocks. Journal of Financial Economics 89: 444-66. [CrossRef]

Karolyi, G. A., K.-H. Lee, and M. A. Van Dijk. 2012. Understanding commonality in liquidity around the world. Journal of Financial Economics 105: 82-112. [CrossRef]

Kilian, L. 2009. Not all oil price shocks are alike: Disentangling demand and supply shocks in the crude oil market. American Economic Review 99: 1053-69. [CrossRef]

Kilian, L. 2015. Why Did the Price of Oil Fall after June 2014? VoxEU.org. Available online: http://voxeu.org/article/causes-2014-oilprice-decline (accessed on 30 June 2021).

Koch, A., S. Ruenzi, and L. Starks. 2016. Commonality in liquidity: A demand-side explanation. Review of Financial Studies 29: 1943-74. [CrossRef]

Korajczyk, R. A., and R. Sadka. 2008. Pricing the commonality across alternative measures of liquidity. Journal of Financial Economics 87: 45-72. [CrossRef]

Marshall, B. R., N. H. Nguyen, and N. Visaltanachoti. 2013. Liquidity commonality in commodities. Journal of Banking E Finance 37: $11-20$.

Morck, R., B. Yeung, and W. Yu. 2000. The information content of stock markets: Why do emerging markets have synchronous stock price movements? Journal of Financial Economics 58: 215-60. [CrossRef]

Moriyasu, H., M. Wee, and J. Yu. 2018. The role of algorithmic trading in stock liquidity and commonality in electronic limit order markets. Pacific-Basin Finance Journal 49: 103-28. [CrossRef]

Moshirian, F., X. Qian, C. K. G. Wee, and B. Zhang. 2017. The determinants and pricing of liquidity commonality around the world. Journal of Financial Markets 33: 22-41. [CrossRef]

Narayan, P. K., and S. S. Sharma. 2011. New evidence on oil price and firm returns. Journal of Banking E Finance 35: $3253-62$.

Park, J., and R. Ratti. 2008. Oil price shocks and stock markets in the U.S. and 13 European countries. Energy Economics 30: 2587-608. [CrossRef]

Pastor, L., and R. F. Stambaugh. 2003. Liquidity risk and expected stock returns. Journal of Political Economy 111: 642-85. [CrossRef]

Rogoff, K. 2016. What's Behind the Drop in Oil Prices? World Economic Forum. Available online: https:/ /www.weforum.org/agenda/ 2016/03/what-s-behind-the-drop-in-oil-prices / (accessed on 30 June 2021).

Roll, R. 1988. R². Journal of Finance 43: 541-66. [CrossRef]

Rösch, C. G., and C. Kaserer. 2013. Market liquidity in the financial crisis: The role of liquidity commonality and flight-to-quality. Journal of Banking \& Finance 37: 2284-302.

Sadorsky, P. 2001. Risk factors in stock returns of Canadian oil and gas companies. Energy Economics 23: 17-28. [CrossRef]

Śmiech, S., M. Papież, M. Rubaszek, and M. Snarska. 2021. The role of oil price uncertainty shocks on oil-exporting countries. Energy Economics 93: 105028. [CrossRef]

Vayanos, D. 2004. Flight to Quality, Flight to Liquidity, and the Pricing of Risk. Cambridge: National Bureau of Economic Research Working Paper.

Yoon, S. M., M. Al Mamun, G. S. Uddin, and S. H. Kang. 2019. Network connectedness and net spillover between financial and commodity markets. The North American Journal of Economics and Finance 48: 801-18. [CrossRef] 